Article

\title{
Genome Wide Transcriptome Analysis Reveals Complex Regulatory Mechanisms Underlying Phosphate Homeostasis in Soybean Nodules
}

\author{
Yingbin Xue ${ }^{1}$, Qingli Zhuang ${ }^{1}$, Shengnan Zhu ${ }^{1}$, Bixian Xiao ${ }^{1}$, Cuiyue Liang ${ }^{1}$, Hong Liao ${ }^{2}$ and \\ Jiang Tian ${ }^{1, *}$ \\ 1 Root Biology Center, State Key Laboratory for Conservation and Utilization of Subtropical Agro-Bioresources, \\ College of Natural Resources and Environment, South China Agricultural University, Guangzhou 510642, \\ China; yingbinxue@yeah.net (Y.X.); 15889964001@163.com (Q.Z.); shnzhu@163.com (S.Z.); \\ 13570450400@163.com (B.X.); liangcy@scau.edu.cn (C.L.) \\ 2 Root Biology Center, Haixia Institute of Science and Technology, Fujian Agriculture and Forestry University, \\ Fuzhou 350000, China; hliao@fafu.edu.cn \\ * Correspondence: jtian@scau.edu.cn; Tel.: +86-208-528-3380
}

Received: 14 September 2018; Accepted: 21 September 2018; Published: 26 September 2018

\begin{abstract}
Phosphorus (P) deficiency is a major limitation for legume crop production. Although overall adaptations of plant roots to $P$ deficiency have been extensively studied, only fragmentary information is available in regard to root nodule responses to P deficiency. In this study, genome wide transcriptome analysis was conducted using RNA-seq analysis in soybean nodules grown under P-sufficient $\left(500 \mu \mathrm{M} \mathrm{KH}_{2} \mathrm{PO}_{4}\right)$ and P-deficient $\left(25 \mu \mathrm{M} \mathrm{KH}_{2} \mathrm{PO}_{4}\right)$ conditions to investigate molecular mechanisms underlying soybean (Glycine max) nodule adaptation to phosphate (Pi) starvation. Phosphorus deficiency significantly decreased soybean nodule growth and nitrogenase activity. Nodule Pi concentrations declined by $49 \%$ in response to P deficiency, but this was well below the $87 \%$ and $88 \%$ decreases observed in shoots and roots, respectively. Nodule transcript profiling revealed that a total of 2055 genes exhibited differential expression patterns between Pi sufficient and deficient conditions. A set of (differentially expressed genes) DEGs appeared to be involved in maintaining Pi homeostasis in soybean nodules, including eight Pi transporters (PTs), eight genes coding proteins containing the SYG1/PHO81/XPR1 domain (SPXs), and 16 purple acid phosphatases $(P A P s)$. The results suggest that a complex transcriptional regulatory network participates in soybean nodule adaption to Pi starvation, most notable a Pi signaling pathway, are involved in maintaining Pi homeostasis in nodules.
\end{abstract}

Keywords: RNA-seq; nodule; P deficiency; symbiotic nitrogen fixation; soybean

\section{Introduction}

Phosphorus (P) is an essential plant macronutrient. As a key component of biomolecules, such as nucleic acids, proteins, and phospholipids, $\mathrm{P}$ is involved in multiple biosynthetic and metabolic processes throughout plant growth and development $[1,2]$. Phosphate (Pi), the major form of phosphorus acquired by plants, is not only unevenly distributed in soils, but is also readily fixed onto soil particles into unavailable forms (e.g., aluminum-P, iron-P, and calcium-P) [3-5]. Low $\mathrm{P}$ availability significantly decreases crop yields, and, thus, becomes a major constraint on crop growth and production [6]. At the other end of the spectrum, excessive application of $P$ fertilizer is inadvisable, due to depletion of limited $\mathrm{P}$ rock resources and eutrophication of marine systems by Pi in runoff that is not utilized by plants [6,7]. Intelligent use of moderate amounts of $P$ fertilizer can be beneficial if crops are developed for such conditions. To meet these goals of developing smart crop cultivars 
with high P utilization efficiency requires further understanding of genetic and molecular mechanisms underlying plant adaptions to P deficiency [8-12].

To date, a range of morphological, physiological and molecular processes have been associated with plant in adaptation to $\mathrm{P}$ deficiency. These processes include the remodeling of root morphology and architecture, increased exudation of organic acids and acid phosphatases, enhanced expression of Pi transporters, and formation of symbiotic interactions with mycorrhizal fungi or rhizobia [13-19]. In recent years, many Pi starvation responsive genes and proteins have been identified and functionally characterized, which has filled in large gaps in our sketch of plant Pi signaling and regulatory networks $[5,9,11]$. In the center of the Pi signaling network lie several important regulators, such as phosphate starvation response 1 (PHR1) and WRKY transcription factors, proteins containing the SYG1/PHO81/XPR1 domain (SPX), and the ubiquitin-like modifier E3 ligase [20-25]. Downstream responses include a set of genes directly involved in morphological and physiological responses to Pi starvation, such as purple acid phosphatase (PAP) genes functioning in extracellular organic $\mathrm{P}$ remobilization, phosphate transporter (Pht) genes involved in Pi acquisition, and expansin (EXP) genes that participate in alteration of root morphology and architecture [26-30].

Among all of the genes, Pht genes are widely characterized in plants, especially in rice (Oryza sativa) and Arabidopsis thaliana. It has been documented that transcripts of a set of Pht genes were increased by Pi starvation, such as 4 of 9 Pht genes in Arabidopsis and 4 of 13 in rice [31,32]. Furthermore, AtPht1;1 and AtPht1;4 are suggested to be responsible for about $50 \%$ of Pi uptake under Pi starvation conditions in Arabidopsis [33,34]. Similarly, OsPht1;1, OsPHT1;9 and OsPHT1;10 were found to modulates phosphate uptake and translocation [35-37]. Recently, several Pht genes have been suggested to regulate root growth, such as AtPht1;5 for root hair formation and primary root growth in Arabidopsis, OsPht1;8 for adventitious root elongation and lateral roots number [38,39]. Another critical gene family in regulating Pi homeostasis, SPX family, has also been well characterized in plants. In Arabidopsis, transcripts of 3 AtSPX members were enhanced by P deficiency except to AtSPX4 [22]. Similar to Arabidopsis, 5 OsSPX members were up-regulated by P deficiency except to OsSPX4 [40]. Recently, a highly conserved mechanism has been suggested that SPX proteins might act as an intracellular Pi sensor mainly through interactions with PHR1/PHR2 in both rice and Arabidopsis [41-45].

Additionally, plant phytohormones are suggested to regulate plant responses to Pi starvation, such as auxin, abscisic acid, ethylene, cytokinin $[9,46,47]$. Furthermore, cross-regulation also occurs between Pi and nitrogen $(\mathrm{N})$ starvation in both legume and non-legume plants [48,49]. For example, a critical regulator for Arabidopsis adaptation to nitrogen availability, $\mathrm{N}$ limitation adaptation (NLA) was suggested to regulate Pi homeostasis by recruiting PHOSPHAT2 (PHO2) to degrade Pht1;4 in Arabidopsis [48]. Furthermore, transcription levels of $N L A$ were found to be regulated by a Pi starvation responsive miR827 [49], strongly suggesting there is a crosstalk between N and P deficiency. For legume plants, a crosstalk between $\mathrm{N}$ and $\mathrm{P}$ deficiency could be directly reflected by significant decreases of both $\mathrm{N}_{2}$ fixation capability and growth in legume nodules by Pi starvation [28,50,51]. However, one outstanding issue is that a large fraction of our knowledge of Pi signaling networks has been attained in model plants, such as Arabidopsis thaliana and rice (Oryza sativa). Verification and application of this knowledge remain fragmentary for most crops, particularly legume crops.

Soybean (Glycine max L.) is an important legume crop that is a source of high-quality protein and oil [52]. Similar to other legumes, soybean participates in symbiosis with rhizobia in the formation of nodules [53]. It has been well documented that rhizobium establishment is a complex process, which is mainly regulated by phytohormones, such as auxin, cytokinin, ethylene, gibberellic acid, strigolactones, jasmonic acid, abscisic acid, and salicylic acid [54,55]. For example, it has been suggested that ethylene negatively regulates rhizobia infection and nodule organogenesis because suppression of both LjEIN2a and LjEIN2b led to a hypernodulation phenotype in Lotus japonicus [56]. Recently, gibberellic acids have been suggested to negatively regulate root nodule symbiosis in Lotus japonicus and Medicago truncatula [57-59]. Furthermore, it has been documented that $P$ availability adversely affects soybean nodule development and growth [60-62]. In addition, it has been suggested that responses to $\mathrm{P}$ 
deficiency are similar between roots and nodules, because of significant increases of proton exudation, and, thus, decreases of rhizosphere $\mathrm{pH}$ were observed in soybean grown in low $\mathrm{P}$ conditions $[18,63]$. However, few studies were conducted to investigate gene expression patterns between nodules and roots in legume crops. For example, it has been documented that 11 of 14 GmPT members exhibited Pi-starvation responsive expression patterns in soybean roots [28,29], but information about transcripts of all GmPT members responsive to Pi-starvation remains largely unknown in soybean nodules. Recently, increased transcription of GmPT5 has been shown to play a critical role in maintaining Pi homeostasis in soybean nodules [62]. Plus, a Pi starvation responsive gene, GmEXPB2, plays vital roles in adaptive responses of both soybean roots and nodules to P deficiency, possibly through cell wall modifications $[26,51]$. The results strongly suggest that identification and functional analysis of Pi starvation responsive gene is critical for elucidating adaptive strategies to low P stress in soybean nodules. Yet, genome-wide transcriptome analysis has not been conducted to identify Pi starvation responsive genes in soybean nodules.

Although genome-wide transcriptome analysis has been successfully used to elucidate molecular mechanisms underlying complex adaptations of plants to P deficiency using RNA-seq technique, most of these studies focus on roots or leaves of plants grown under non-symbiotic conditions. Little transcriptome information is available for legume nodules. As far as the authors are aware, only three studies have been conducted to investigate global gene expression responses to Pi starvation in legume nodules, including with bean (Phaseolus vulgaris), Medicago truncatula and chickpea (Cicer arietinum) [64-66]. However, there is little information about genome-wide analysis of gene transcripts responsive to Pi starvation in soybean nodule. Furthermore, it is well known that the formation of symbiotic nodules and their responses to Pi starvation varies considerably among legume species and rhizobium strains $[66,67]$. Thus, it is important to investigate molecular mechanisms underlying nodule development and physiology for each commercially important legume crop under Pi starvation.

In this study, genome-wide transcriptomic analysis of soybean nodules in response to P deficiency was conducted via RNA-seq. Thousands of differentially expressed genes were identified in soybean nodules under P deficiency, with many involved in nutrient/ion transport, transcriptional regulation, key metabolic pathways, Pi remobilization, and signaling. These results will enable future researchers to further elucidate molecular processes within nodules adapted to P deficiency, which will ultimately lead to the development of P-efficient soybean varieties that can maintain symbiotic nitrogen fixation (SNF) in low or moderate P availability systems.

\section{Results}

\subsection{Growth of Soybean Nodules Is Inhibited by Pi Starvation}

Phosphate starvation significantly affects soybean nodule growth. The results in this study showed that nodule size, fresh weight, and nitrogenase activity in nodules declined in response to Pi starvation by $27 \%, 36 \%$, and $45 \%$, respectively (Figure $1 \mathrm{a}, \mathrm{b}, \mathrm{d}, \mathrm{e}$ ). However, there was no significant difference between phosphorus treatments in nodule number (Figure 1c). Consistently, Pi starvation significantly reduced both $\mathrm{P}$ content and total $\mathrm{P}$ concentration of seedlings and nodules (Figure 2a,b). Compared to values in $\mathrm{HP}$ plants, the $\mathrm{P}$ content and total $\mathrm{P}$ concentration of shoots and roots decreased by more than $70 \%$, whereas, the P content and total P concentration in nodules decreased only by $55 \%$ and $49 \%$, respectively, under LP conditions (Figure 2a,b). Accompanying decreases in P content, soluble $\mathrm{Pi}$ concentrations also decreased significantly in response to Pi starvation, with observed soluble $\mathrm{Pi}$ concentrations declining by $88 \%$ in leaves, $98 \%$ in roots, and $77 \%$ in nodules (Figure $2 \mathrm{c}$ ). In contrasting, acid phosphatase (APase) activity increased significantly with P deprivation, as reflected by $0.4,6.9$, and 1.2-fold increases in leaves, roots, and nodules, respectively (Figure 2d). Furthermore, the highest APase activities were observed in nodules, especially with low $\mathrm{P}$ availability, where this activity was 2.3 and 3.7 fold higher than in leaves and roots, respectively (Figure 2d). 
(a)

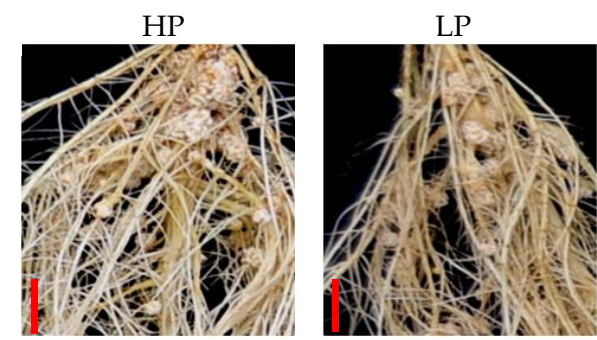

(b)

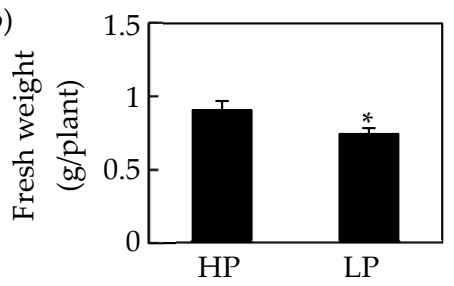

(d)

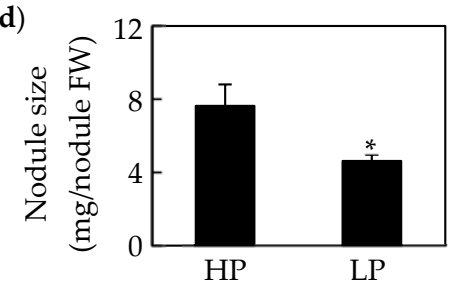

(c)

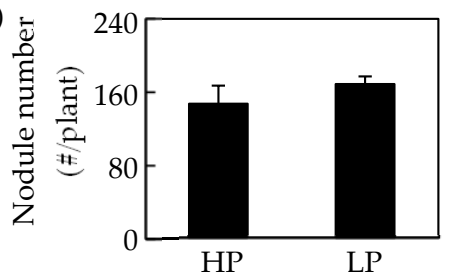

(e)

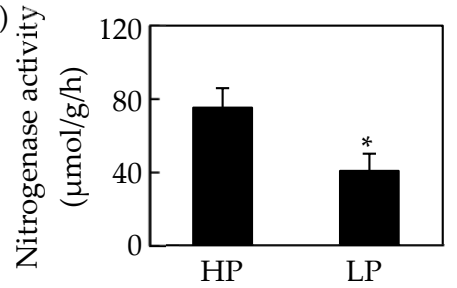

Figure 1. Effects of phosphorus (P) deficiency on soybean nodule growth. (a) Phenotype of soybean nodules at two P levels. (b) Soybean fresh weight. (c) Nodule number. (d) Nodule size. (e) Nodule nitrogenase activity. Data in the figure are mean of four replicates with standard error bars. Asterisks indicate significant difference between $\mathrm{HP}\left(500 \mu \mathrm{M} \mathrm{KH}_{2} \mathrm{PO}_{4}\right)$ and $\mathrm{LP}\left(25 \mu \mathrm{M} \mathrm{KH}_{2} \mathrm{PO}_{4}\right)$ treatments in the Student's $t$-test $\left({ }^{*}: p<0.05\right)$. Bars $=1 \mathrm{~cm}$.

(a)

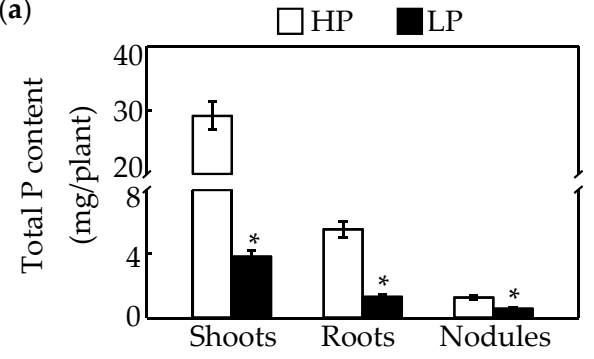

(c)

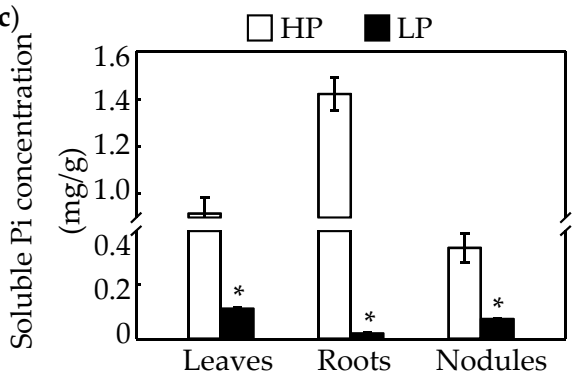

(b)

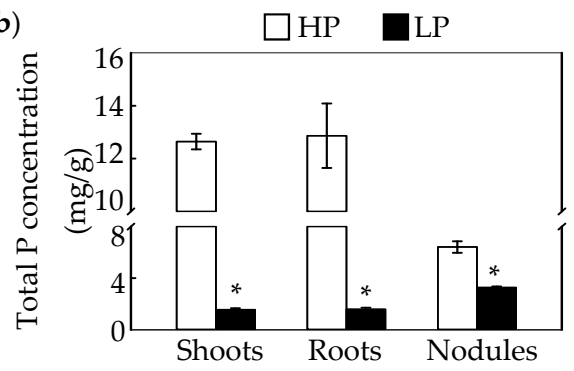

(d)

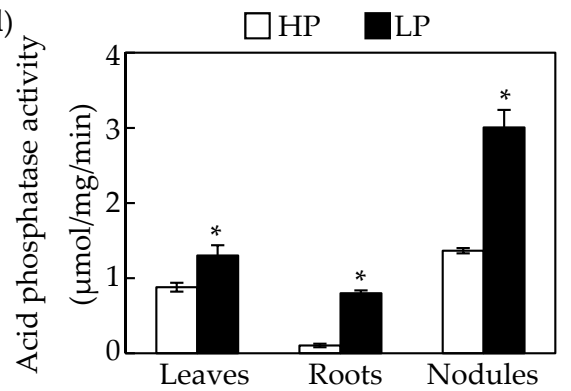

Figure 2. Effects of $\mathrm{P}$ deficiency on phosphate (Pi) accumulation and acid phosphatase (APase) activity in soybean. (a) Total P content of shoots, roots, and nodules. (b) Total Pi concentrations in shoots, roots, and nodules. (c) Soluble Pi concentrations in leaves, roots, and nodules. (d) Acid phosphatase activity of leaves, roots, and nodules. Data in the figure are mean of four replicates with standard error bars. Asterisks indicate significant difference between HP and LP treatments in the Student's t-test $(*: p<0.05)$. 


\subsection{Amino-N Compounds in Nodules Produced in Low P and High P Conditions}

The amino acid/amide composition in HP or LP treated nodules was analyzed to check for effects of $\mathrm{P}$ availability on $\mathrm{N}$ metabolism. A total of 25 amino- $\mathrm{N}$ compounds were detected, and $\mathrm{P}$ deficiency significantly affected the concentrations of many, as well as, their relative proportions in soybean nodules (Table 1). Under P deficient conditions, the concentration of total amino-N compounds increased by $35 \%$ compared to that under P sufficient conditions. Closer inspection of individual compounds revealed that the $\mathrm{P}$ deficiency led to increased concentrations of six amino-N compounds, namely asparagine, glutamine, arginine, histidine, phosphoethanolamine and isoleucine, with the largest increase of 8.2-fold observed for phosphoethanolamine (Table 1). On the other side, the concentration of four amino-N compounds decreased significantly with Pi starvation, including glutamic acid, aspartic acid, $\beta$-Alanine, and cysteine (Table 1). Despite these differences, asparagine remained the most prevalent amino- $\mathrm{N}$ compound in soybean nodules, as reflected by this compound comprising $69 \%$ and $79 \%$ of the total amino-N compounds in HP and LP treated nodules, respectively (Table 1).

Table 1. Amino acid composition in soybean nodules under phosphate (Pi) sufficient $(\mathrm{HP}, 500 \mu \mathrm{M}$ $\mathrm{KH}_{2} \mathrm{PO}_{4}$ ) and deficient (LP, $25 \mu \mathrm{M} \mathrm{KH} \mathrm{PO}_{4}$ ) conditions.

\begin{tabular}{|c|c|c|c|c|c|}
\hline & \multirow{2}{*}{$\begin{array}{c}\text { HP } \\
\mu g / g \text { FW }\end{array}$} & \multicolumn{3}{|c|}{ LP } & \multirow{2}{*}{$\log _{2}(\mathrm{LP} / \mathrm{HP})$} \\
\hline & & $\%$ & $\mu \mathrm{g} / \mathrm{g}$ FW & $\%$ & \\
\hline Asparagine & $3225.00 \pm 570.99$ & 69.47 & $5039.99 \pm 720.71$ & 79.83 & $0.64 *$ \\
\hline Glutamic acid & $619.90 \pm 45.82$ & 13.35 & $285.56 \pm 32.07$ & 4.52 & $-1.12 *$ \\
\hline$\gamma$-Aminobutyric acid & $148.83 \pm 9.96$ & 3.21 & $134.97 \pm 23.90$ & 2.14 & -0.14 \\
\hline Serine & $118.56 \pm 9.95$ & 2.55 & $117.30 \pm 0.88$ & 1.86 & -0.02 \\
\hline Aspartic acid & $107.75 \pm 8.35$ & 2.32 & $68.12 \pm 8.58$ & 1.08 & $-0.66^{*}$ \\
\hline Alanine & $62.91 \pm 4.19$ & 1.36 & $53.39 \pm 22.40$ & 0.85 & -0.24 \\
\hline Tryptophane & $51.22 \pm 3.52$ & 1.10 & $42.19 \pm 5.36$ & 0.67 & -0.28 \\
\hline Glutamine & $43.98 \pm 53.87$ & 0.95 & $84.27 \pm 33.24$ & 1.33 & 0.94 \\
\hline Arginine & $43.30 \pm 4.81$ & 0.93 & $155.11 \pm 12.52$ & 2.46 & $1.84 *$ \\
\hline$\beta$-Alanine & $39.17 \pm 4.00$ & 0.84 & $30.68 \pm 2.15$ & 0.49 & $-0.35 *$ \\
\hline Phosphoserine & $34.65 \pm 1.88$ & 0.75 & $33.11 \pm 2.49$ & 0.52 & -0.07 \\
\hline Histidine & $30.23 \pm 3.20$ & 0.65 & $135.99 \pm 7.34$ & 2.15 & $2.17 *$ \\
\hline Threonine & $23.54 \pm 3.23$ & 0.51 & $22.33 \pm 2.22$ & 0.35 & -0.08 \\
\hline Phenylalanine & $18.79 \pm 2.42$ & 0.40 & $17.25 \pm 1.68$ & 0.27 & -0.12 \\
\hline Tyrosine & $12.91 \pm 4.17$ & 0.28 & $11.63 \pm 1.44$ & 0.18 & -0.15 \\
\hline Lysine & $12.10 \pm 1.71$ & 0.26 & $13.32 \pm 1.72$ & 0.21 & 0.14 \\
\hline Citrulline & $10.17 \pm 4.09$ & 0.22 & $7.28 \pm 1.69$ & 0.12 & -0.48 \\
\hline Glycine & $8.31 \pm 1.29$ & 0.18 & $8.86 \pm 0.66$ & 0.14 & 0.09 \\
\hline Isoleucine & $5.92 \pm 0.55$ & 0.13 & $10.24 \pm 0.38$ & 0.16 & 0.79 * \\
\hline Cystine & $5.89 \pm 0.75$ & 0.13 & $3.90 \pm 1.28$ & 0.06 & $-0.59 *$ \\
\hline Leucine & $4.89 \pm 1.48$ & 0.11 & $5.49 \pm 0.94$ & 0.09 & 0.17 \\
\hline Valine & $4.71 \pm 0.83$ & 0.10 & $3.48 \pm 0.33$ & 0.06 & -0.44 \\
\hline Ornithine & $3.54 \pm 1.20$ & 0.08 & $2.52 \pm 0.78$ & 0.04 & -0.49 \\
\hline Methionine & $3.18 \pm 0.09$ & 0.07 & $2.25 \pm 1.18$ & 0.04 & -0.5 \\
\hline Phosphorylethanolamine & $2.64 \pm 1.13$ & 0.06 & $24.30 \pm 0.56$ & 0.38 & $3.20 *$ \\
\hline Total & 4642.09 & 100 & 6313.53 & 100 & \\
\hline
\end{tabular}

The fold change of the amino acid concentration between HP and LP conditions was calculated as the logarithm of $\mathrm{LP} / \mathrm{HP}$ to the base 2 (i.e., $\log _{2}(\mathrm{LP} / \mathrm{HP})$ ). Data in the table are means of three replicates with standard error. Asterisks indicate significant difference between HP and LP treatment $\left(^{*}: p<0.05\right)$. 


\subsection{Changes of Transcriptomes in Soybean Nodules Resulting from Pi Starvation}

Transcriptome analysis of soybean nodules in response to Pi starvation was determined by RNA-seq analysis. A total of six libraries were constructed. RNA-seq analysis produced about 47.6 and 48.1 million raw reads for nodules at HP and LP levels, respectively (Table S1). After excluding the low-quality readings, about 45.6 and 46.2 million clean reads were obtained for libraries of HP and LP nodules, respectively (Table S1). Among them, a total of 42.8 and 43.3 million clean reads perfectly mapped to soybean reference genes for each P treatments (Table S1). Finally, a total of 38,831 and 38,874 gene transcripts were found to be expressed in P-sufficient and P-deficient nodules, respectively (Table 2). Differentially expressed genes (DEGs) were those with transcripts observed to have at least 2 -fold changes in expression, as well as, $q$ value $\leq 0.05$. Using these criteria, a total of 2055 genes were considered to be differently expressed in soybean nodules between the two P treatments (Table 2). Among them, 1431 genes were up-regulated by P deficiency, while 624 genes were down-regulated (Table 2 and Table S2). Gene ontology (GO) category analysis showed that the 2055 Pi-responsive genes could be divided among 22 biological processes, 14 cellular component, and 11 molecular function terms (Figure S1). Among these categories, cellular process, cell part, and binding function were the most prevalent among biological process, cellular component and molecular function terms, respectively (Figure S1).

Table 2. Gene number identified through RNA-seq analysis.

\begin{tabular}{cccc}
\hline & Total Expressed Genes & Up-Regulated & Down-Regulated \\
\hline HP & 38,813 & & \\
LP & 38,874 & & 624 \\
DEGs * & 2055 & 1431 & \\
* DEGs: Differentially expressed genes between Pi sufficient (HP) and deficient (LP) soybean nodules.
\end{tabular}

\subsection{Analysis of Pi-Responsive Genes Involved in Metabolome}

MapMan analysis was further used to examine DEGs in soybean nodules. The expression ratios of LP/HP were utilized and graphical representations were obtained for visual analysis from MapMan (Figure 3). In total, the differentially expressed genes were predicted to participate in 22 metabolic processes (Figure 3). However, Pi-starvation responsive genes were mainly associated with lipid metabolism (55 genes), hormone metabolism (46 genes), cell wall (44 genes), and secondary metabolism (31 genes). Of the remaining categories, 18, 17, 15, 13,11, and 10 genes were respectively associated with minor $\mathrm{CHO}$ (carbohydrate) metabolism, nucleotide metabolism, major $\mathrm{CHO}$ metabolism, redox, photosynthesis process, and glycolysis (Figure S2). At the low end of representation, less than five genes were predicated to be involved in C1 (one carbon)-metabolism, TCA (Tricarboxylic Acid) transformation, gluconeogenesis/glyoxylate cycle, polyamine metabolism, mitochondrial electron transport/ATP synthesis, fermentation, tetrapyrrole synthesis, S-assimilation, N-metabolism, co-factor, and vitamin metabolism, and biodegradation of xenobiotics (Figure S2). Furthermore, 16 genes were identified to be involved in amino acid metabolism (Table S3). Among them, a total of nine genes were up-regulated by Pi starvation, including three asparagine synthetases, two ornithine decarboxylases, two lysine decarboxylases, one glutamine synthetase, and glutamyl-tRNA (Gln) amidotransferase subunit $C$ (Table S3). However, a total of seven genes were down-regulated by Pi starvation, including two histidine decarboxylases, two S-adenosylmethionine decarboxylases, one cysteine synthase, tyrosine aminotransferase, and lysine decarboxylase (Table S3). 


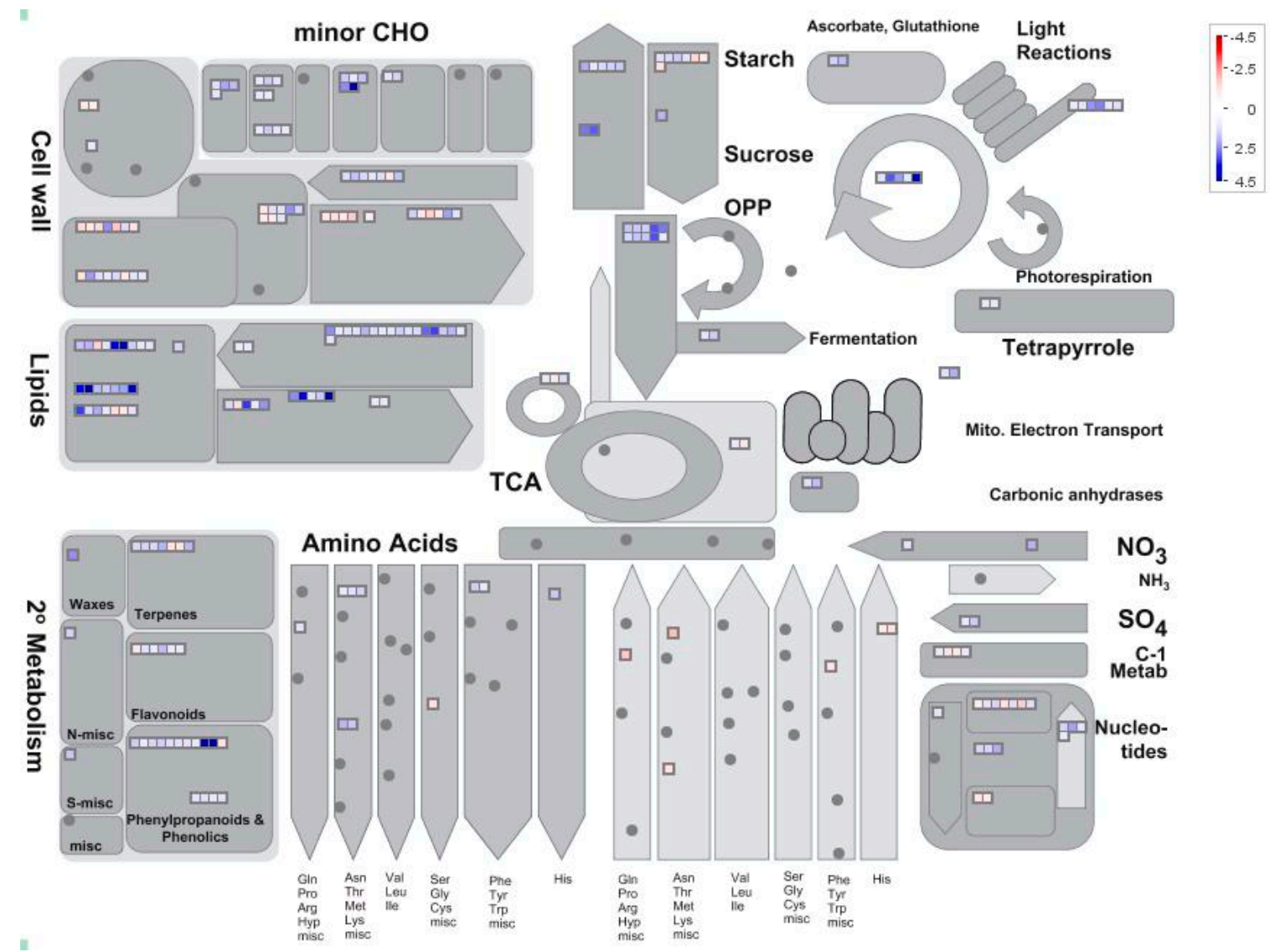

Figure 3. MapMan analysis of differentially expressed genes in soybean nodules. In the color scale, blue and red represent up-regulated and down-regulated expression, respectively, in response to Pi starvation within soybean nodules. Black dots represent no gene enrichment to the category entries. Numbers represent fold changes in expression levels expressed as $\log _{2}(\mathrm{LP} / \mathrm{HP})$.

\subsection{Identification of Pi-Starvation Responsive Genes Controlling Nodule Pi Homeostasis}

Since soybean nodules are a P sink, three gene families involved in Pi homeostasis were further analyzed among DEGs, including PT (Phosphate Transporter), PAP (Purple Acid Phosphatase) and SPX (proteins containing the SYG1/PHO81/XPR1 domain). Out of 14 GmPT members, eight were significantly enhanced in nodules in response to P deficiency (Table 3). Among them, more than 16-fold increases were observed for transcripts of GmPT5 and GmPT6 in P-deficient nodules (Table 3). Phylogenetic analysis showed that GmPT proteins encoded by eight Pi-starvation responsive GmPT members were classified into two sub-groups (Figure S4). GmPT1/4/7/13 were classified into sub-group I, with MtPT1/2/3/5 and AtPht1;1/2/3. However, GmPT2/5/6/14 belonged to sub-group II with AtPht1;4/7 (Figure S4). For SPX family, eight GmSPX members were significantly up-regulated in nodules by Pi starvation, especially GmSPX9 with a 168 -fold increase (Table 3). Phylogenetic analysis showed all proteins encoded by Pi-starvation responsive GmSPXs were classified into three sub-groups, including sub-group I, II, and V (Figure S5). GmSPX3/7/8 were classified into sub-group I, containing PvSPX1/2, and AtSPX1/2 (Figure S4). Sub-group II contained GmSPX2/4/5/9 and PvSPX3 (Figure S5). GmSPX1/10 belonged to sub-group V with AtSPX3 and OsSPX3/5/6 (Figure S5). For the PAP family, 16 members were significantly up-regulated, most of all, GmPAP11 with a 41-fold increase in expression (Table 3). Phylogenetic analysis showed that all identified GmPAPs were classified into four sub-groups (Figure S6). GmPAP11/20/23 were classified into sub-group I, with PvPAP2, SgPAP10, AtPAP10, AtPAP12, OsPAP10a, and OsPAP10c (Figure S6). GmPAP21/31/32 belonged to sub-group III together with OsPAP21b/23, AtPAP15/23 (Figure S6). GmPAP1/17/30/35, together with OsPAP9b, AtPAP2/9 
belonged to sub-group IV (Figure S6). GmPAP8/9/10/13/15/16 belonged to sub-group V with PvPAP3, SgPAP7 and AtPAP17 (Figure S6).

Table 3. Differentially expressed genes involved in Pi homeostasis.

\begin{tabular}{cccc}
\hline Accession No. & Name/Description & Log $_{\mathbf{2}}$ (LP/HP) & Q Value \\
\hline Glyma.02G005800 & GmPT1 & 1.15 & $3.0 \times 10^{-2}$ \\
Glyma.03G162800 & GmPT2 & 1.41 & $1.34 \times 10^{-15}$ \\
Glyma.10G006700 & GmPT4 & 3.99 & $1.12 \times 10^{-45}$ \\
Glyma.10G036800 & GmPT5 & 4.04 & $2.84 \times 10^{-166}$ \\
Glyma.10G186400 & GmPT6 & 4.01 & $2.56 \times 10^{-30}$ \\
Glyma.10G186500 & GmPT7 & 2.28 & $5.85 \times 10^{-50}$ \\
Glyma.20G204000 & GmPT13 & 1.82 & $1.3 \times 10^{-13}$ \\
Glyma.20G204100 & GmPT14 & 3.67 & $1.02 \times 10^{-21}$ \\
Glyma.02G117000 & GmPAP1 & 2.15 & $3.94 \times 10^{-15}$ \\
Glyma.05G138400 & GmPAP8 & 3.03 & $3.05 \times 10^{-43}$ \\
Glyma.05G247900 & GmPAP9 & 2.45 & $5.49 \times 10^{-93}$ \\
Glyma.05G247800 & GmPAP10 & 2.28 & $4.15 \times 10^{-29}$ \\
Glyma.06G028200 & GmPAP11 & 5.41 & $1.90 \times 10^{-239}$ \\
Glyma.08G056400 & GmPAP13 & 2.43 & $1.11 \times 10^{-84}$ \\
Glyma.08G093500 & GmPAP15 & 2.19 & $2.92 \times 10^{-46}$ \\
Glyma.08G093600 & GmPAP16 & 2.29 & $8.75 \times 10^{-47}$ \\
Glyma.08G291600 & GmPAP17 & 1.70 & $2.33 \times 10^{-19}$ \\
Glyma.09G229200 & GmPAP20 & 3.70 & $3.36 \times 10^{-162}$ \\
Glyma.10G071000 & GmPAP21 & 4.61 & $9.92 \times 10^{-78}$ \\
Glyma.12G007500 & GmPAP23 & 3.14 & $3.07 \times 10^{-110}$ \\
Glyma.18G132500 & GmPAP30 & 1.29 & $3.01 \times 10^{-13}$ \\
Glyma.19G026600 & GmPAP31 & 4.86 & $1.32 \times 10^{-73}$ \\
Glyma.19G193900 & GmPAP32 & 1.81 & $2.24 \times 10^{-4}$ \\
Glyma.20G026800 & GmPAP35 & 1.66 & $1.02 \times 10^{-35}$ \\
Glyma.01G135500 & GmSPX1 & 6.35 & 0 \\
Glyma.04G067400 & GmSPX2 & 2.09 & $1.39 \times 10^{-5}$ \\
Glyma.04G147600 & GmSPX3 & 4.55 & $9.01 \times 10^{-105}$ \\
Glyma.06G069000 & GmSPX4 & 5.89 & $5.27 \times 10^{-124}$ \\
Glyma.10G261900 & GmSPX5 & 1.99 & $2.31 \times 10^{-14}$ \\
Glyma.13G166800 & GmSPX7 & 3.41 & $4.79 \times 10^{-103}$ \\
Glyma.17G114700 & GmSPX8 & 3.52 & $1.03 \times 10^{-73}$ \\
Glyma.20G129000 & GmSPX9 & 7.40 & $2.6 \times 10^{-118}$ \\
\hline & & & \\
\hline
\end{tabular}

\subsection{Identification of Genes Functioning as Transporters}

In addition to Pi high affinity transporters, a total of 16 other types of transporters were also identified as responsive to P deficiency in soybean nodules (Figure 4 and Table S4). Among them, genes encoding $\mathrm{ABC}$ transporters were the most abundant, and then the amino acid transporters, with 14 and eight of each type, respectively, identified as P responsive in soybean nodules (Figure 4). Of these, all of $14 \mathrm{ABC}$ transporters were up-regulated, while seven amino acid transporters were up-regulated and one was down-regulated (Figure 4).

In regard to transport of other molecules containing nitrogen, two nitrate transporters, Glyma.13G323800 (i.e., GmNRT2) [68] and Glyma.17G124900, were significantly down- and up-regulated in response to $\mathrm{P}$ deficiency, respectively, while one ammonium transporter was up-regulated in nodules (Figure 4), which suggests that P deficiency significantly influences $\mathrm{N}$ acquisition and translocation in nodules (Figure 4). Moreover, P deficiency led to significant increases in the transcription of three sugar transporters, two glycerol-3-phosphate transporters, two ascorbate transporters, one nucleoside transporter, one nucleobase-ascorbate transporter, and one organic cation/carnitine transporter, while decreases in the transcription of two aluminum-activated malate transporters in soybean nodules (Figure 4). 
In regard to transport of other mineral nutrients, down-regulation was observed for two sulfate transporters and one boron transporter (Figure 4). On the other hand, up-regulation was observed for four sulfate transporters, two iron transporters, a single boron transporter, potassium transporter, and NRAMP metal ion transporter (Figure 4). These results suggest that P deficiency significantly influences the acquisition or translocation of many nutrients and metabolites in nodules.

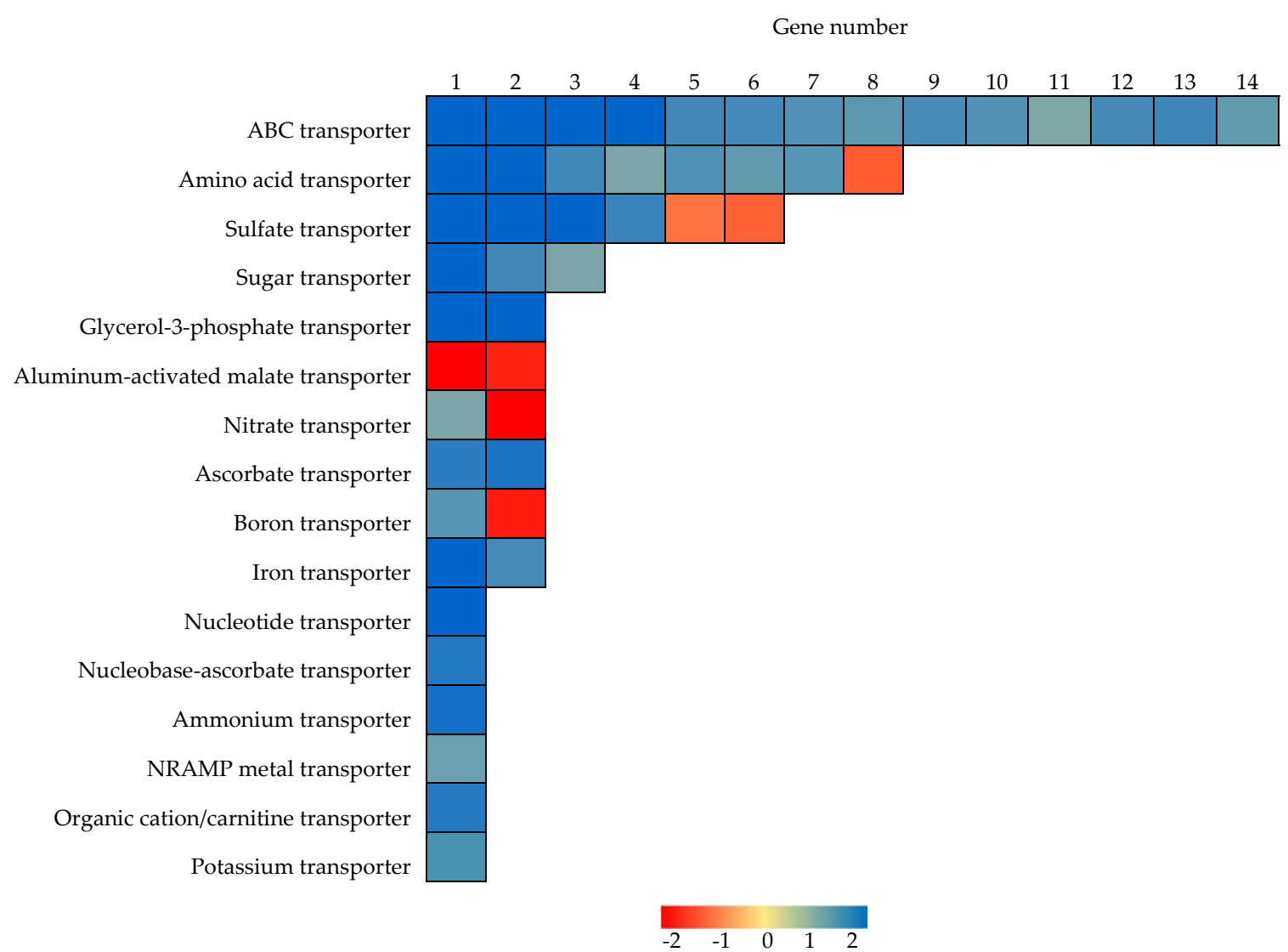

Figure 4. Heatmap analysis of $P$ responsive DEGs associated with transport in nodules. Blue and red represent up-regulated and down-regulated expression, respectively, in response to Pi starvation within soybean nodules. Numbers represent fold changes in expression levels expressed as $\log _{2}(\mathrm{LP} / \mathrm{HP})$.

\subsection{Genes Involved in Hormonal Signaling Pathways}

A total of 38 genes involved in hormonal signaling were differentially expressed in response to Pi starvation, which affected four types of hormone signaling pathways. These DEGs included 11 genes involved in auxin signaling, two in cytokinin (CK) signaling, 22 in ethylene signaling, and three in gibberellin (GA) signaling (Table 4). Furthermore, nine out of 11 auxin signaling DEGs, one out of two CK signaling DEGs, 19 out of 22 ethylene signaling DEGs, and all of the GA signaling DEGs were up-regulated by Pi starvation in nodules (Table 4). These results suggest that $\mathrm{P}$ deficiency affects growth and development in nodules partially through hormone signaling networks. 
Table 4. Differentially expressed genes involved in hormonal signaling.

\begin{tabular}{|c|c|c|c|c|}
\hline Hormone & Accession No. & Name/Description & $\log _{2}(\mathrm{LP} / \mathrm{HP})$ & $Q$ Value \\
\hline \multirow{11}{*}{ Auxin } & Glyma.02G142400 & AUX/IAA family auxin-responsive protein & 2.25 & $3.56 \times 10^{-8}$ \\
\hline & Glyma.02G142500 & AUX/IAA family auxin-responsive protein & 2.28 & $5.80 \times 10^{-16}$ \\
\hline & Glyma.04G025300 & AUX/IAA family auxin-responsive protein & 1.91 & $3.46 \times 10^{-24}$ \\
\hline & Glyma.05G196300 & AUX/IAA family auxin-responsive protein & 1.58 & $4.80 \times 10^{-7}$ \\
\hline & Glyma.09G193000 & AUX/IAA family auxin-responsive protein & 1.06 & $3.69 \times 10^{-2}$ \\
\hline & Glyma.10G031900 & SAUR family auxin-responsive protein & 1.86 & $7.77 \times 10^{-6}$ \\
\hline & Glyma.10G056200 & SAUR family auxin-responsive protein & -1.07 & $9.92 \times 10^{-4}$ \\
\hline & Glyma.12G035700 & SAUR family auxin-responsive protein & 1.84 & $5.57 \times 10^{-5}$ \\
\hline & Glyma.13G361200 & SAUR family auxin-responsive protein & 1.06 & $2.09 \times 10^{-6}$ \\
\hline & Glyma.16G020800 & SAUR family auxin-responsive protein & -1.27 & $1.70 \times 10^{-2}$ \\
\hline & Glyma.19G206100 & Auxin response factor & 2.16 & $7.42 \times 10^{-6}$ \\
\hline \multirow{2}{*}{ Cytokinin } & Glyma.04G055600 & Cytokinin dehydrogenase & -1.25 & $2.96 \times 10^{-3}$ \\
\hline & Glyma.20G159600 & Cytokinin hydroxylase & 1.56 & $1.95 \times 10^{-3}$ \\
\hline \multirow{22}{*}{ Ethylene } & Glyma.01G206600 & AP2-like ethylene response factor & 1.18 & $3 \times 10^{-2}$ \\
\hline & Glyma.02G132500 & AP2-like ethylene response factor & 1.90 & $2.06 \times 10^{-5}$ \\
\hline & Glyma.05G063500 & AP2-like ethylene response factor & 1.12 & $3.03 \times 10^{-4}$ \\
\hline & Glyma.06G236400 & AP2-like ethylene response factor & 1.09 & $6.61 \times 10^{-6}$ \\
\hline & Glyma.07G113800 & AP2-like ethylene response factor & 1.28 & $4.46 \times 10^{-3}$ \\
\hline & Glyma.07G212400 & AP2-like ethylene response factor & 2.60 & $1.05 \times 10^{-18}$ \\
\hline & Glyma.09G072000 & AP2-like ethylene response factor & 2.30 & $2.54 \times 10^{-10}$ \\
\hline & Glyma.10G118900 & AP2-like ethylene response factor & 1.01 & $7.27 \times 10^{-6}$ \\
\hline & Glyma.10G194200 & AP2-like ethylene response factor & 1.23 & $6.20 \times 10^{-3}$ \\
\hline & Glyma.12G110400 & AP2-like ethylene response factor & 1.04 & $4 \times 10^{-2}$ \\
\hline & Glyma.12G203100 & AP2-like ethylene response factor & 1.32 & $3.03 \times 10^{-4}$ \\
\hline & Glyma.13G040400 & AP2-like ethylene response factor & -1.13 & $2 \times 10^{-2}$ \\
\hline & Glyma.13G112400 & AP2-like ethylene response factor & 2.16 & $1.95 \times 10^{-6}$ \\
\hline & Glyma.15G180000 & AP2-like ethylene response factor & 2.87 & $3.81 \times 10^{-16}$ \\
\hline & Glyma.17G047300 & AP2-like ethylene response factor & 1.20 & $3 \times 10^{-2}$ \\
\hline & Glyma.17G070800 & AP2-like ethylene response factor & 1.25 & $6.47 \times 10^{-3}$ \\
\hline & Glyma.17G145300 & AP2-like ethylene response factor & 1.26 & $1.54 \times 10^{-5}$ \\
\hline & Glyma.18G281400 & AP2-like ethylene response factor & -1.35 & $3.86 \times 10^{-4}$ \\
\hline & Glyma.19G256800 & AP2-like ethylene response factor & 1.27 & $2 \times 10^{-2}$ \\
\hline & Glyma.20G070100 & AP2-like ethylene response factor & 1.93 & $2.56 \times 10^{-9}$ \\
\hline & Glyma.20G172800 & AP2-like ethylene response factor & -1.18 & $2 \times 10^{-2}$ \\
\hline & Glyma.14G041500 & EIN3-like ethylene response factor & 1.32 & $8.33 \times 10^{-19}$ \\
\hline \multirow{3}{*}{ Gibberellin } & Glyma.12G137700 & Gibberellin-responsive protein & 1.44 & $7.13 \times 10^{-4}$ \\
\hline & Glyma.13G285400 & Gibberellin-responsive protein & 1.49 & $2.82 \times 10^{-8}$ \\
\hline & Glyma.19G013000 & Gibberellin-regulated protein & 1.06 & $3 \times 10^{-2}$ \\
\hline
\end{tabular}

\section{8. $\mathrm{Ca}^{2+}$ Signaling Related Genes in Soybean Nodules Regulated by P Deficiency}

A total of $24 \mathrm{Ca}^{2+}$ signaling related DEGs were identified in P-deficient soybean nodules, including two coding calmodulin-like proteins, three genes for annexins, two for calcium ATPases, four for calcium-dependent protein kinase, 12 for calcium-binding proteins, and one calmodulin-binding transcription activator (Table 5). Among these $24 \mathrm{Ca}^{2+}$ signaling related DEGs, 19 were up-regulated and five were down-regulated, including one annexin gene, three genes coding for calcium-binding proteins, and one gene encoding a calcium-dependent protein kinase (Table 5). 
Table 5. Differentially expressed genes involved in $\mathrm{Ca}^{2+}$ signaling.

\begin{tabular}{cccc}
\hline Accession No. & Name/Description & Log $_{\mathbf{2}}$ (LP/HP) & $Q$ Value \\
\hline Glyma.05G085200 & Annexin & 1.86 & $8.71 \times 10^{-9}$ \\
Glyma.05G178200 & Annexin & 1.18 & $7.92 \times 10^{-16}$ \\
Glyma.10G002200 & Annexin-like & -1.29 & $4.65 \times 10^{-14}$ \\
Glyma.01G166100 & Calmodulin-binding transcription activator & 1.76 & $2.47 \times 10^{-17}$ \\
Glyma.02G059200 & Calcium-transporting ATPase & 1.66 & $4.21 \times 10^{-13}$ \\
Glyma.02G245700 & Calcium-transporting ATPase & 1.44 & $4.46 \times 10^{-13}$ \\
Glyma.03G138000 & Calmodulin-like protein & -1.03 & $3.38 \times 10^{-4}$ \\
Glyma.04G064800 & Calmodulin-like protein & 1.43 & $3.68 \times 10^{-5}$ \\
Glyma.04G136200 & Calcium-binding protein & 1.32 & $1.40 \times 10^{-4}$ \\
Glyma.05G047100 & Calcium uptake protein & 1.15 & $2 \times 10^{-2}$ \\
Glyma.05G199400 & Calcium-binding protein & 1.47 & $5.09 \times 10^{-4}$ \\
Glyma.06G171100 & Calcium-binding protein & 1.06 & $4 \times 10^{-2}$ \\
Glyma.07G229500 & Calcium-binding protein & 1.56 & $8.46 \times 10^{-6}$ \\
Glyma.08G006900 & Calcium-binding protein & -1.19 & $5.63 \times 10^{-3}$ \\
Glyma.11G048300 & Calcium-binding protein & 1.50 & $2.93 \times 10^{-4}$ \\
Glyma.11G077300 & Calcium-binding protein & 1.16 & $3.34 \times 10^{-3}$ \\
Glyma.11G157100 & Calcium-binding protein & 1.11 & $2 \times 10^{-2}$ \\
Glyma.12G217700 & Calcium-binding protein & 2.23 & $1.37 \times 10^{-9}$ \\
Glyma.14G156300 & Calcium-binding protein & -1.48 & $2.72 \times 10^{-3}$ \\
Glyma.14G222000 & Calcium-binding protein & 1.58 & $2.06 \times 10^{-20}$ \\
Glyma.16G142100 & Calcium-binding protein & 1.12 & $1.60 \times 10^{-9}$ \\
Glyma.17G128900 & Calcium-dependent protein kinase & 1.40 & $1.65 \times 10^{-6}$ \\
Glyma.20G034200 & Calcium-dependent protein kinase & 1.06 & $1.73 \times 10^{-4}$ \\
Glyma.20G066800 & Calcium-dependent protein kinase & 1.55 & $9.09 \times 10^{-16}$ \\
Glyma.05G248000 & Calcium-dependent protein kinase & -1.08 & $2.08 \times 10^{-4}$ \\
\hline & & &
\end{tabular}

\subsection{Transcription Factors in Soybean Nodules Regulated by P Deficiency}

A total of 71 putative transcription factor genes responded significantly to $\mathrm{P}$ deficiency in soybean nodules (Figure 5). Among them, genes related to WRKY transcription factors were the most abundant, with 15 being up-regulated and two down-regulated (Figure 5). The remaining transcription factor DEGS were observed as follows. Thirteen $\mathrm{C} 2 \mathrm{H} 2$ family DEGs were up-regulated, but one was down-regulated, $11 M Y B$ family DEGs were up-regulated and one down-regulated, five $b H L H$ family DEGs were up-regulated and four down-regulated, four $b$ ZIP family DEGs were up-regulated and one down-regulated, and three GRAS family DEGs were up-regulated and two down-regulated (Figure 5). Interestingly, five NAC members, four C3HC4 members, three PLATZ members, and two MADS members identified in nodules were up regulated by P deficiency (Figure 5).

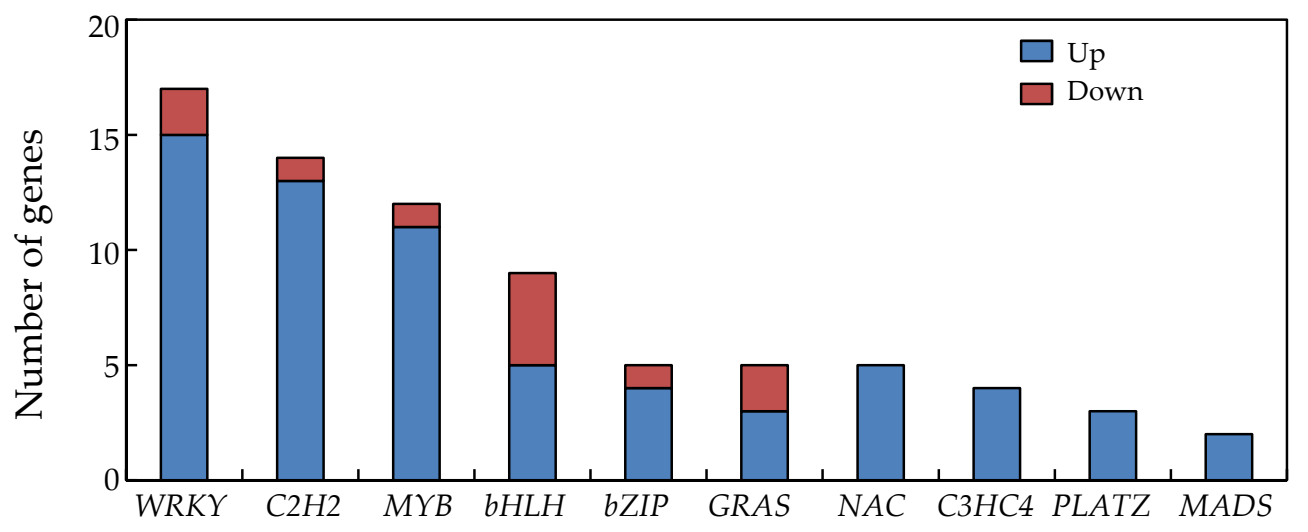

Figure 5. Differentially expressed genes associated with transcription factor activity in soybean nodules. 


\subsection{Analysis of Gene Transcripts Using qRT-PCR}

To confirm results from the RNA-seq analysis, qRT-PCR analysis was further conducted with 10 up-regulated DEGs in nodules at two P levels. All of these genes were significantly up-regulated by Pi starvation in soybean nodules as determined by qRT-PCR procedures, which strongly supports the reliability of the RNA-seq results (Figure 6 and Figure S3). Among the transcripts subjected to qRT-PCR analysis, respective increases of over 7-fold and 3-fold were observed for two Pi transporters genes, GmPT5 and GmPT7 (Figure 6). One SPX gene (GmSPX5), two purple acid phosphatase genes (GmPAP8 and GmPAP21) exhibited 4-, 11-, and 17-fold increases, respectively, in LP plants relative to those in the HP treatment (Figure 6). In qRT-PCR analysis of the tested transcription factor DEGs, bZIP (Glyma.04G022100) was up-regulated more than 2-fold, bHLH (Glyma.11G043700) was up-regulated more than 2.8-fold, and the tested WRKY (Glyma.16G026400) was up-regulated about 3.3-fold in nodules subjected to P deficiency (Figure 6). Finally, the hormonal signaling ethylene response factors, ERF1 (Glyma.01G206600) and ERF2 (Glyma.04G022100) were up regulated by 2.5and 2.3-fold, respectively (Figure 6).
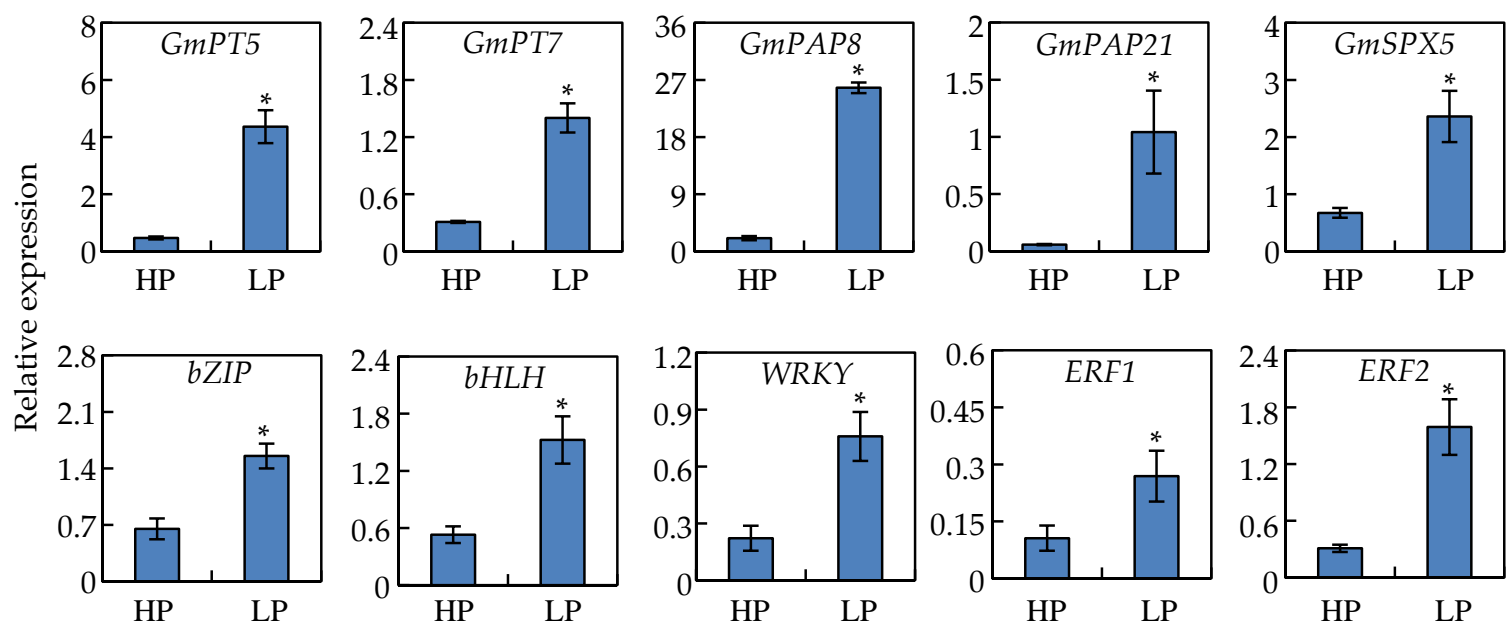

Figure 6. qRT-PCR analysis of ten Pi responsive genes in soybean nodules under Pi sufficient (HP) and deficient (LP) conditions. Data in the figure are mean of four replicates with standard error. Asterisks indicate significant difference between HP and LP treatments in the Student's $t$-test $\left({ }^{*}: p<0.05\right)$.

\section{Discussion}

Leguminous plants form nodules through symbiotic interactions with rhizobium species. These organs are the sites of SNF, which provide nitrogen for host plants. However, it is well documented that $\mathrm{P}$ deficiency significantly influences nodule growth and development in legume plants, such as in soybean, common bean, Medicago truncatula, and chickpea $[61,62,64-66]$. Consistently, in this study, P deficiency also led to significant inhibition of nodule growth and development, as reflected by decreases in nitrogenase activity, nodule fresh weight and nodule size with Pi starvation (Figure 1). However, relative to effects on leaves and roots, decreases of total P content, soluble Pi concentration, and total P concentration in nodules were less affected by Pi starvation (Figure 1), strongly suggesting that nodules are $\mathrm{P}$ sinks with a high capability of maintaining Pi homeostasis to reduce adverse effects of $P$ deficiency on nodule growth and development $[60,62,65,66]$.

With the aid of genome-wide analysis of gene expression through microarray or RNA-seq approaches, a group of Pi starvation responsive genes have been identified in plant leaves and roots, which has facilitated the elucidation of adaptive strategies employed by plants to minimize the detrimental effects of P deficiency through functional characterization of these DEGs [11,69-73]. Recently, with the aid of RNA-seq approaches, genome wide analysis of Pi starvation responsive genes in legume nodules has been studied, with the host plants being common bean, Medicago truncatula and 
chickpea [64-66]. Common responses of legume nodules to Pi starvation could be demonstrated by identifying a set of DEGs with high homology among three legume species, such as WRKY, MYB and NAC [64-66]. However, it seems that more complex responses of soybean nodules to Pi starvation were elucidated as reflected by identification of 2055 Pi-starvation responsive genes, which was more than 495 in bean, 1140 in Medicago truncatula and 540 in chickpea [64-66]. For example, 8 GmPT members and GmSPX members were found to be responsive to Pi starvation in soybean nodules, but only 1 SPX member in Medicago truncatula, 1 PT member and SPX member in chickpea have been identified [64-66]. Furthermore, it seems that a set of genes preferring to increase transcripts in soybean nodules at low P levels were identified in the current study, such as GmPT5, GmSPX1, and GmPAP11/30. For example, among eight Pi-starvation up-regulated GmSPX members in soybean nodules, GmSPX1 has been documented to exhibit no response to Pi starvation in soybean roots [74]. Meanwhile, transcription of GmPAP11/30 was found to have no response to Pi starvation in soybean roots [27], suggesting complex responses of soybean nodules to Pi starvation.

Enhanced Pi mobilization and acquisition through increased exudation of organic acids and purple acid phosphatase, along with up-regulation of Pi transporters are well-documented strategies employed by plant roots in response to P deficiency [75-81]. Nodules exhibit similar responses to roots in response to $\mathrm{P}$ deprivation, with up-regulation of genes related to Pi mobilization and acquisition, such as Pi transporters, and purple acid phosphatases, which allows for the maintenance of Pi homeostasis in nodules (Table 3 and Figure 4). In this study, eight out of 14 GmPT members were significantly enhanced in nodules as a result of P deficiency (Table 3). Among them, Pi starvation up-regulated GmPT5 might mediate Pi homeostasis in soybean nodules through control of Pi translocation from roots to nodules [35]. In the present study, other three GmPT members (i.e., GmPT2/6/14) were found to be up-regulated by Pi starvation, strongly suggesting other GmPT members could mediate Pi acquisition and translocation in soybean nodules at low P level except to GmPT5 [62], which merits further analysis.

Accompanying increases in the abundance of nine GmPT transcripts, 16 PAP transcripts were also observed as differentially expressed in nodules subjected to Pi starvation, which is consistent with observations of significantly increased APase activity in P deprived nodules (Table 3 and Figure 2). Increased PAP transcription and APase activity are well known to play vital roles in the regulation of internal P metabolism and extracellular organic P mobilization in plants $[82,83]$. Although functions of several GmPAP have been documented, including the involvement of GmPhy and GmPAP4 in phytate-P mobilization, and the participation of GmPAP3 in ROS metabolism in plants under salt stress, functions of most Pi starvation up-regulated GmPAPS, except GmPAP21, remain largely unknown [84-87]. GmPAP21 overexpression leads to nodule growth inhibition in soybean, suggesting that it participates in internal P metabolism within soybean nodules [87]. Furthermore, it was observed that organic-P utilization was enhanced in rhizobia inoculated in soybean, it is reasonable to hypothesize that Pi starvation responsive GmPAPs might also be involved in extracellular organic-P utilization in soybean [18]. Among Pi starvation up-regulated GmPAPs, GmPAP11/20/23 exhibited high homology with SgPAP10 in stylo functions as mediating extracellular organic-P utilization [81], suggesting that GmPAP11/20/23 might contribute to extracellular organic-P utilization in soybean nodules.

In addition to GmPT and GmPAP, two GmSPX genes, GmSPX1 and GmSPX3, are also potentially vital regulators of Pi signaling pathways in soybean [74,88]. Interestingly, GmSPX1 and GmSPX3, together with six other GmSPX members were found to be significantly up-regulated in soybean nodules upon Pi starvation (Table 3). This indicates that GmSPX members are good candidates for genes involved in maintaining Pi homeostasis in soybean nodules.

In addition to differential expression associated with Pi acquisition and mobilization, many Pi-starvation responsive DEGs in soybean nodules were associated with nitrate/nitrite absorption and assimilation (Figure S2). Similarly, Pi starvation can lead to significant increases in the concentrations of total amino acids and asparagine in common bean and chickpea [64,89]. Furthermore, consistent with increased asparagine accumulation, three asparagine synthetase genes were found to 
be up-regulated by Pi starvation in soybean nodules (Table 1 and Table S3), strongly suggesting that Pi starvation significantly influences amino acid accumulations in nodules. Increased asparagine accumulation is known to inhibit the capacity for SNF in nodules, suggesting that asparagine plays a role in N feedback regulation of SNF [90-92]. Plus, nitrogenase activity has been severely curtailed through phloem-feeding of asparagine, which further implicates asparagine as a phloem-mobile shoot-born factor that functions in systemic feedback regulation of SNF [91]. However, these previous investigations did not include experiments of $\mathrm{P}$ effects. Therefore, further investigation of regulatory mechanisms underlying amino acid synthesis and transport involving nodules in responses to Pi starvation remains as a relevant subject for future researchers.

In this study, 38 plant hormone-related genes were identified as DEGs in response to $\mathrm{P}$ deprivation (Table 4). This indicates that a variety of signaling pathways within nodules participate in responses to Pi starvation. For example, two genes (Glyma.10G056200 and Glyma.16G020800) coding auxin-responsive proteins were down-regulated, while one auxin responsive factor (Glyma.19G206100) and 5 AUX/IAA family members were up-regulated by Pi starvation in soybean nodules (Table 4). This suggests that auxin is involved in nodule adaptation to Pi starvation. However, specific roles for auxin signaling in adaptive strategies of nodules to Pi starvation remain unknown. Although miR160 can negatively regulate AUXIN RESPONSE FACTOR10 (ARF10), and, thus, increase auxin sensitivity and inhibit soybean nodule development [93], none of these genes were found to be significantly regulated by Pi starvation in the present study (Table 4). Therefore, other auxin pathways might also regulate nodule responses to Pi starvation, which requires further investigation for more conclusive evidence.

Calcium signaling was also found to be important in the current work, as $24 \mathrm{Ca}^{2+}$ signaling related genes were found to be regulated by Pi starvation in soybean nodules, including two calmodulin-like and four calcium-dependent protein kinase. This suggests that low P availability affects $\mathrm{Ca}^{2+}$ signaling, and thereby regulates nodule development (Table 5). Consistent with this result, sustained oscillation of calcium concentrations is known to activate the expression of symbiosis-related genes after perception of rhizobia-derived nodulation factors [94,95]. Meanwhile, CCaMK, a nuclear calcium- and calmodulin-dependent kinase has been suggested as the central regulator in symbiotic development in plants [96]. All these results strongly suggest that $\mathrm{Ca}^{2+}$ signaling is also involved in regulating soybean nodule adaptations to Pi starvation.

Finally, significant alterations of transcriptional regulation are implied by the presence of 76 transcription factors among the DEGs responsive to $P$ deficiency in soybean nodules. These numbers include 12 MYB and five GRAS transcription factors (Figure 5). Although functions of MYB and GRAS transcription factors remains largely unknown in soybean nodule development and responses to Pi starvation, one MYB transcription factor, $L j I P N 2$, has been documented as capable of binding directly to the NIN gene promoter and, thus, play an important role in the Nod signaling pathway in Lotus japonicas [97]. Meanwhile, it has been reported that the GRAS family transcription factors, MtNSP1 and MtNSP2 form a protein complex that is essential for root nodule symbiosis in Medicago truncatula [98]. The results herein are consistent with these previous reports and further suggest that complex transcriptional regulatory networks participate in soybean nodule adaption to Pi starvation.

\section{Materials and Methods}

\subsection{Plant, Rhizobium and Growth Conditions}

The soybean (Glycine max L.) genotype YC03-3 and rhizobium strain USDA110 were selected for hydroponic experiments. Seeds were sterilized and germinated in paper rolls for 4 days. Before transplanting, roots of uniform seedlings were inoculated with rhizobia. The nutrient solution contained $\mathrm{KNO}_{3} 311.3 \mu \mathrm{M}, \mathrm{NH}_{4} \mathrm{NO}_{3} 94.3 \mu \mathrm{M}, \mathrm{MgCl}_{2} 25 \mu \mathrm{M}, \mathrm{MgSO}_{4} \cdot 7 \mathrm{H}_{2} \mathrm{O} 500 \mu \mathrm{M}, \mathrm{K}_{2} \mathrm{SO}_{4} 300 \mu \mathrm{M}$, $\mathrm{MnSO}_{4} \cdot \mathrm{H}_{2} \mathrm{O} 1.5 \mu \mathrm{M}, \mathrm{ZnSO}_{4} \cdot 7 \mathrm{H}_{2} \mathrm{O} 1.5 \mu \mathrm{M}, \mathrm{CuSO}_{4} \cdot 5 \mathrm{H}_{2} \mathrm{O} 0.5 \mu \mathrm{M},\left(\mathrm{NH}_{4}\right)_{5} \mathrm{MoO}_{24} \cdot 4 \mathrm{H}_{2} \mathrm{O} 0.16 \mu \mathrm{M}$,

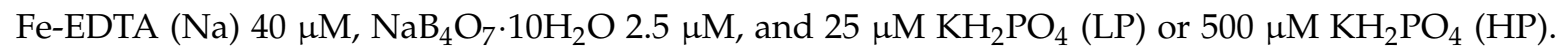


The $\mathrm{pH}$ value was adjusted to approximately 5.8 , and the nutrient solution was changed weekly. Leaves, roots, and nodules were harvested 25 days after transplanting.

\subsection{Determination of Total P and Soluble Pi Concentrations}

Total Pi and soluble Pi concentrations were analyzed as described previously [62]. For the total $\mathrm{P}$ concentration measurements, about $0.2 \mathrm{~g}$ dry weight of shoots, roots, and nodules from each $\mathrm{P}$ treatment was separately digested for each tissue in $\mathrm{H}_{2} \mathrm{SO}_{4}$, and further boiled and digested at $300{ }^{\circ} \mathrm{C}$ until the solution became clear. For soluble Pi concentrations, about $0.1 \mathrm{~g}$ of fresh samples of soybean leaves, roots, and nodules were sampled separately and ground in deionized water for extraction. The supernatant was collected after centrifugation at $12,000 \times \mathrm{g}$ for $30 \mathrm{~min}$. Total and soluble Pi concentrations were determined as described by Murphy and Riley [99].

\subsection{Acid Phosphatase Activity Measurements}

Acid phosphatase activities of leaves, roots, and nodules were assessed as described previously [77]. Briefly, about $0.1 \mathrm{~g}$ of fresh samples were ground and extracted for soluble protein using $100 \mathrm{mM}$ Tris- $\mathrm{HCl}$ ( $\mathrm{pH} 8.0$ ). Reaction mixtures containing $1 \mathrm{mM} \varrho$-nitrophenyl phosphate ( $\varrho-\mathrm{NPP}$, Sigma, Saint Louis, MO, USA), $2 \mathrm{~mL}$ of $45 \mathrm{mM} \mathrm{Na}$-acetate buffer ( $\mathrm{pH}$ 5.0) and protein extract were incubated at $37^{\circ} \mathrm{C}$ for $15 \mathrm{~min}$ before halting reactions via the addition of $1 \mathrm{~mL}$ of $1 \mathrm{M} \mathrm{NaOH}$. Absorbance was measured at $405 \mathrm{~nm}$. The concentration of soluble protein was analyzed using Coomassie Brilliant Blue staining [100]. Acid phosphatase activity was presented as micromoles of $\varrho$-NPP hydrolyzed per milligram of protein per minute.

\subsection{Nodule Nitrogenase Activity Analysis}

Nodules attached roots were cut off to measure nitrogenase activity by the acetylene reduction assay [101]. Fresh nodules were incubated in a closed container with $10 \%(v / v)$ acetylene gas for $2 \mathrm{~h}$ at $28^{\circ} \mathrm{C}$ prior to extracting $1 \mathrm{~mL}$ of reacted gas samples from the headspace using a syringe. Ethylene content was calculated from peak areas of standards analyzed by gas chromatography. Nitrogenase activity was calculated as $\mu$ mole ethylene $\mathrm{h}^{-1} \cdot \mathrm{g}^{-1}$ nodules.

\subsection{Amino Acid Analysis}

The amino acid compositions of nodules were analyzed in an automatic amino acid analyzer (type L-8800, Hitachi Ltd., Tokyo, Japan), as described previously [102]. Briefly, about $0.1 \mathrm{~g}$ of fresh samples were cut off and ground in 5\% 5-sulfosalicylic acid dehydrated for the extraction. The supernatant was collected after centrifugation at $12,000 \times g$ at $4{ }^{\circ} \mathrm{C}$ for $30 \mathrm{~min}$. Separation column $(4.6 \mathrm{~mm} \times 60 \mathrm{~mm})$ parameters: eluent flow rate $=0.4 \mathrm{~mL} / \mathrm{min}$, column temperature $=70^{\circ} \mathrm{C}$, and column pressure $=11.627 \mathrm{MPa}$. Reaction column parameters: ninhydrin buffer run at a flow rate of $0.35 \mathrm{~mL} / \mathrm{min}$, column temperature $=135^{\circ} \mathrm{C}$, column pressure $=1.078 \mathrm{MPa}$. The detection threshold for amino-N compounds was $1 \mu \mathrm{g} \cdot \mathrm{g}^{-1}$ fresh weight in nodules.

\section{6. cDNA Library Preparation, RNA-Seq and Phylogenetic Analysis}

After 25 days, nodules with the size more than $3 \mathrm{~mm}$ were collected for mRNA library construction and sequencing. Nodules from two plants were pooled together as one replicate, and three replicates from each P treatment were used for RNA-seq analysis. Total RNA of nodules was isolated using Trizol reagent (Invitrogen, Carlsbad, CA, USA) according to the manufacturer's protocol. The quantity and purity of total RNA was checked using an Agilent 2100 RNA Nano 6000 Assay Kit (Agilent Technologies, Palo Alto, CA, USA). About $3 \mu \mathrm{g}$ of total RNA was subjected to mRNA enrichment using oligo (dT) attached magnetic beads (Invitrogen). The mRNA was then fragmented into small pieces using fragmentation buffer, which was then used as template strands. The first strand of cDNA was synthesized by random hexamers, then added buffer, dNTPs, RNase $\mathrm{H}$, and DNA polymerase 
I was added for synthesizing the second chain. Through QiaQuick PCR amplification, purification and EB buffer elution, end repair, addition of adenosine and sequencing joints, target size fragments were recovered by agarose gel electrophoresis prior to performing and PCR amplification. Sequencing was performed on the Illumina HiSeq X Ten platform, and the sequencing program was PE150. To obtain clean reads, the adaptor sequences, low quality sequences, and unknown nucleotides were removed from the raw reads. Bowtie2 software (version 2.2.3) was used for building the genome index, and clean reads were then aligned to the reference genome (Glycine max Williams82.a2.v1) using HISAT2 software (version 2.1.0) with no more than one nucleotide mismatch allowed, the alignment results were identified and estimated through Cufflinks (version 2.2.0) [103]. Gene expression levels were normalized through fragments per kilobase million mapped reads (FPKM) method [104] and are shown in Table S5. DESeq2 v1.6.3 was designed for differential gene expression analysis between P-deficient and P-sufficient nodules. The expression level of each gene per sample was estimated by the linear regression, then the $p$-value was calculated with Wald test, finally the $p$-value was corrected by the $\mathrm{BH}$ method, and genes with $q \leq 0.05$ and $\left|\log _{2}(\mathrm{LP} / \mathrm{HP})\right| \geq 1$ were identified as differentially expressed genes (DEGs) [105]. GO functional enrichment analysis using the DAVID (Database for Annotation, Visualization and Integrated Discovery) [106]. Visualization of metabolic pathways was achieved using MapMan software [107]. Phylogeny analysis was conducted by MEGA 5.05, using the neighbor-joining method with 1000 bootstrap replicates as described previously [108]. All the original RNA-Seq data have been submitted to the NCBI Gene Expression Omnibus under the accession number of GSE116593.

\section{7. qRT-PCR Analysis}

Total RNA from nodules was separately extracted using Trizol reagent (Invitrogen, Carlsbad, CA, USA). After treating with DNase I, the reverse transcription kit (Promega, Madison, WI, USA) was used to synthesize first-strand complementary DNA. The qRT-PCR analysis was performed by SYBR Green monitored qPCR (Takara, Kyoto, Japan) and carried out on a Rotor-Gene 3000 qPCR system (Corbett Research, Mortlake, Australia), with the following reaction conditions: $95^{\circ} \mathrm{C}$ for $30 \mathrm{~s}, 40$ cycles of $95^{\circ} \mathrm{C}$ for $5 \mathrm{~s}, 60^{\circ} \mathrm{C}$ for $15 \mathrm{~s}$, and $72{ }^{\circ} \mathrm{C}$ for $30 \mathrm{~s}$. Three biological replications were included. Relative expression levels were calculated as the ratio of candidate gene expression to housekeeping gene TefS1 (Glyma.17G186600) expression as described previously [51]. The primers for qRT-PCR analysis are shown in Table S6.

\subsection{Statistical Analysis}

Statistical analysis was performed using Microsoft Excel 2010 (Microsoft Company, Redmond, WA, USA). Significant differences between treatments were evaluated by statistical comparison performed using Student's t-test.

\section{Conclusions}

Phosphorus deficiency severely inhibited soybean nodule growth and symbiotic nitrogen fixation. However, soybean nodules exhibited a superior capability of maintaining Pi homeostasis, as reflected by smaller effects of Pi starvation on nodule Pi concentration than in either soybean leaves or roots. With the aid of genome wide RNA-seq analysis, a total of 2055 genes were identified as differentially expressed genes between Pi sufficient and deficient conditions, suggesting that multiple complex transcriptional regulatory networks act in soybean nodule adaption to Pi starvation. Furthermore, a set of DEGs can be associated though annotations and previous work with maintenance of nodule Pi homeostasis. This set includes eight PTs, 8 SPXs, and 16 PAPS, which further supports the conclusion that multiple regulatory pathways are involved in maintaining Pi homeostasis through effects on $\mathrm{Pi}$ acquisition, translocation, and mobilization in soybean nodules. Taken together, this dataset will be valuable for further efforts to elucidate molecular mechanisms underlying soybean nodule adaption to P deficiency. 
Supplementary Materials: Supplementary materials can be found at http:/ / www.mdpi.com/1422-0067/19/10/ 2924/s1, References [109-113] were referred to in supplementary Figures S4 and S6.

Author Contributions: Y.X., J.T., and H.L. conceived and designed the experiments. Y.X. and B.X. performed the experiments. Y.X., Q.Z., C.L., S.Z. and J.T. analyzed the data. Y.X. and J.T. wrote the manuscript. All authors have read and approved the final manuscript.

Funding: This research was funded by the National Natural Science Foundation of China (31872164, 31422046 and 31372119), National Key Research and Development Program of China (2016YFD0100700), Nature Science Foundation of Guangdong Province (2015A030306034), the High Level Talents Special Support Plan of Guangdong Province (2015TX01N042 and 2015TQ01N078), and the Research Team Project of the Natural Science Foundation of Guangdong Province (2016A030312009).

Acknowledgments: We thank Thomas Walk of Golden Fidelity LLC for critically reading the manuscript.

Conflicts of Interest: The authors declare no conflict of interest.

\section{Abbreviations}

$\begin{array}{ll}\text { SNF } & \text { Symbiotic Nitrogen Fixation } \\ \text { RNA-seq } & \text { RNA sequencing } \\ \text { DEGs } & \text { Differentially Expressed Genes } \\ \text { qRT-PCR } & \text { quantitative Real-Time Polymerase Chain Reaction } \\ \text { GO } & \text { Gene Ontology } \\ \text { CK } & \text { Cytokinin } \\ \text { GA } & \text { Gibberellin } \\ \text { CHO } & \text { Carbohydrate }\end{array}$

\section{References}

1. Raghothama, K.G. Phosphate acquisition. Annu. Rev. Plant Biol. 1999, 50, 665-693. [CrossRef] [PubMed]

2. Richardson, A.E. Regulating the phosphorus nutrition of plants: Molecular biology meeting agronomic needs. Plant Soil 2009, 322, 17-24. [CrossRef]

3. Beardsley, T.M. Peak phosphorus. Bioscience 2011, 61, 91. [CrossRef]

4. Veneklaas, E.J.; Lambers, H.; Bragg, J.; Finnegan, P.M.; Lovelock, C.E.; Plaxton, W.C.; Price, C.A.; Scheible, W.R.; Shane, M.W.; White, P.J.; et al. Opportunities for improving phosphorus-use efficiency in crop plants. New Phytol. 2012, 195, 306-320. [CrossRef] [PubMed]

5. Zhang, Z.; Liao, H.; Lucas, W. Molecular mechanisms underlying phosphate sensing, signaling and adaptation in plants. J. Integr. Plant Biol. 2014, 56, 192-220. [CrossRef] [PubMed]

6. Vance, C.P.; Uhde-Stone, C.; Allan, D.L. Phosphorus acquisition and use: Critical adaptations by plants for securing a nonrenewable resource. New Phytol. 2003, 157, 423-447. [CrossRef]

7. Cordell, D.; Drangert, J.O.; White, S. The story of phosphorus: Global food security and food for thought. Glob. Environ. Chang. 2009, 19, 292-305. [CrossRef]

8. Wang, X.; Yan, X.; Liao, H. Genetic improvement for phosphorus efficiency in soybean: A radical approach. Ann. Bot. 2010, 106, 215-222. [CrossRef] [PubMed]

9. Chiou, T.J.; Lin, S.I. Signaling network in sensing phosphate availability in plants. Annu. Rev. Plant Biol. 2011, 62, 185-206. [CrossRef] [PubMed]

10. Tian, J.; Wang, X.; Tong, Y.; Chen, X.; Liao, H. Bioengineering and management for efficient phosphorus utilization in crops and pastures. Curr. Opin. Biotechnol. 2012, 23, 866-871. [CrossRef] [PubMed]

11. Liang, C.; Wang, J.; Zhao, J.; Tian, J.; Liao, H. Control of phosphate homeostasis through gene regulation in crops. Curr. Opin. Plant Biol. 2014, 21, 59-66. [CrossRef] [PubMed]

12. Lópezarredondo, D.L.; Leyvagonzález, M.A.; Gonzálezmorales, S.I.; Lópezbucio, J.; Herreraestrella, L. Phosphate nutrition: Improving low-phosphate tolerance in crops. Annu. Rev. Plant Biol. 2014, 65, 95-123. [CrossRef] [PubMed]

13. Tian, J.; Liao, H.; Wang, X.; Yan, X. Phosphorus starvation-induced expression of leaf acid phosphatase isoforms in soybean. Acta Bot. Sin. 2003, 45, 1037-1042. [CrossRef] 
14. Zhao, J.; Fu, J.; Liao, H.; He, Y.; Nian, H.; Hu, Y.; Qiu, L.; Dong, Y.; Yan, X. Characterization of root architecture in an applied core collection for phosphorus efficiency of soybean germplasm. Chin. Sci. Bull. 2004, 49, 1611-1620. [CrossRef]

15. Liao, H.; Wan, H.; Shaff, J.; Wang, X.; Yan, X.; Kochian, L.V. Phosphorus and aluminum interactions in soybean in relation to aluminum tolerance. Exudation of specific organic acids from different regions of the intact root system. Plant Physiol. 2006, 141, 674-684. [CrossRef] [PubMed]

16. Liu, L.; Liao, H.; Wang, X.R.; Yan, X.L. Regulation effect of soil P availability on mycorrhizal infection in relation to root architecture and P efficiency of Glycine max. Chin. J. Appl. Ecol. 2008, 19, 564-568.

17. Plaxton, W.C.; Tran, H.T. Metabolic adaptations of phosphate starved plants. Plant Physiol. 2011, 156, 1006-1015. [CrossRef] [PubMed]

18. Qin, L.; Jiang, H.; Tian, J.; Zhao, J.; Liao, H. Rhizobia enhance acquisition of phosphorus from different sources by soybean plants. Plant Soil 2011, 349, 25-36. [CrossRef]

19. Liang, C.; Tian, J.; Liao, H. Proteomics dissection of plant responses to mineral nutrient deficiency. Proteomics 2013, 13, 624-636. [CrossRef] [PubMed]

20. Rubio, V.; Linhares, F.; Solano, R.; Martin, A.C.; Iglesias, J.; Leyva, A.; Paz-Ares, J. A conserved MYB transcription factor involved in phosphate starvation signaling both in vascular plants and in unicellular algae. Genes Dev. 2001, 15, 2122-2133. [CrossRef] [PubMed]

21. Miura, K.; Rus, A.; Sharkhuu, A.; Yokoi, S.; Karthikeyan, A.S.; Raghothama, K.G.; Baek, D.; Koo, Y.D.; Jin, J.B.; Bressan, R.A.; et al. The Arabidopsis SUMO E3 ligase SIZ1 controls phosphate deficiency responses. Proc. Natl. Acad. Sci. USA 2005, 102, 7760-7765. [CrossRef] [PubMed]

22. Duan, K.; Yi, K.; Dang, L.; Huang, H.; Wu, W.; Wu, P. Characterization of a sub-family of Arabidopsis genes with the SPX domain reveals their diverse functions in plant tolerance to phosphorus starvation. Plant J. 2008, 54, 965-975. [CrossRef] [PubMed]

23. Wang, H.; Xu, Q.; Kong, Y.H.; Chen, Y.; Duan, J.Y.; Wu, W.H.; Chen, Y.F. Arabidopsis WRKY45 transcription factor activates PHOSPHATE TRANSPORTER1;1 expression in response to phosphate starvation. Plant Physiol. 2014, 164, 2020-2029. [CrossRef] [PubMed]

24. Yao, Z.F.; Liang, C.Y.; Zhang, Q.; Chen, Z.J.; Xiao, B.X.; Tian, J.; Liao, H. SPX1 is an important component in the phosphorus signaling network of common bean regulating root growth and phosphorus homeostasis. J. Exp. Bot. 2014, 65, 3299-3310. [CrossRef] [PubMed]

25. Zhou, Z.; Wang, Z.; Lv, Q.; Shi, J.; Zhong, Y.; Wu, P.; Ma, C. SPX proteins regulate Pi homeostasis and signaling in different subcellular level. Plant Signal. Behav. 2015, 10, e1061163. [CrossRef] [PubMed]

26. Guo, W.; Zhao, J.; Li, X.; Qin, L.; Yan, X.; Liao, H. A soybean $\beta$-expansin gene GmEXPB2 intrinsically involved in root system architecture responses to abiotic stresses. Plant J. 2011, 66, 541-552. [CrossRef] [PubMed]

27. Li, C.; Gui, S.; Yang, T.; Walk, T.; Wang, X.; Liao, H. Identification of soybean purple acid phosphatase genes and their expression responses to phosphorus availability and symbiosis. Ann. Bot. 2012, 109, $275-285$. [CrossRef] [PubMed]

28. Qin, L.; Guo, Y.; Chen, L.; Liang, R.; Gu, M.; Xu, G.; Zhao, J.; Walk, T.; Liao, H. Functional characterization of 14 Pht 1 family genes in yeast and their expressions in response to nutrient starvation in soybean. PLoS ONE 2012, 7, e47726. [CrossRef] [PubMed]

29. Fan, C.; Wang, X.; Hu, R.; Wang, Y.; Xiao, C.; Jiang, Y.; Zhang, X.; Zheng, C.; Fu, Y.F. The pattern of Phosphate transporter 1 genes evolutionary divergence in Glycine max L. BMC Plant Biol. 2013, 13, 48. [CrossRef] [PubMed]

30. Li, X.; Zhao, J.; Walk, T.C.; Liao, H. Characterization of soybean $\beta$-expansin genes and their expression responses to symbiosis, nutrient deficiency, and hormone treatment. Appl. Microbiol. Biotechnol. 2014, 98, 2805-2817. [CrossRef] [PubMed]

31. Mudge, S.R.; Rae, A.L.; Diatloff, E.; Smith, F.W. Expression analysis suggests novel roles for members of the Pht1 family of phosphate transporters in Arabidopsis. Plant J. 2002, 31, 341-353. [CrossRef] [PubMed]

32. Ai, P.; Sun, S.; Zhao, J.; Xu, G. Regulation and function of Pht1 family phosphate transporters in rice. In Proceedings of the International Plant Nutrition Colloquium XVI; Department of Plant Sciences, UC Davis: Davis, CA, USA, 2009. Available online: http://escholarship.org/uc/item/3657w1q3 (accessed on 2 September 2018). 
33. Misson, J.; Thibaud, M.C.; Bechtold, N.; Raghothama, K.; Nussaume, L. Transcriptional regulation and functional properties of Arabidopsis Pht1;4, a high affinity transporter contributing greatly to phosphate uptake in phosphate deprived plants. Plant Mol. Biol. 2004, 55, 727-741. [CrossRef] [PubMed]

34. Shin, H.; Shin, H.S.; Dewbre, G.R.; Harrison, M.J. Phosphate transport in Arabidopsis: Pht1;1 and Pht1;4 play a major role in phosphate acquisition from both low- and high-phosphate environments. Plant J. 2004, 39, 629-642. [CrossRef] [PubMed]

35. Sun, S.; Gu, M.; Cao, Y.; Huang, X.; Zhang, X.; Ai, P.; Zhao, J.; Fan, X.; Xu, G. A constitutive expressed phosphate transporter, OsPht1;1, modulates phosphate uptake and translocation in phosphate-replete rice. Plant Physiol. 2012, 159, 1571-1581. [CrossRef] [PubMed]

36. Wang, X.; Wang, Y.; Piñeros, M.A.; Wang, Z.; Wang, W.; Li, C.; Wu, Z.; Kochian, L.V.; Wu, P. Phosphate transporters OsPHT1;9 and OsPHT1;10 are involved in phosphate uptake in rice. Plant Cell Environ. 2014, 37, 1159-1170. [CrossRef] [PubMed]

37. Zhang, F.; Sun, Y.; Pei, W.; Jain, A.; Sun, R.; Cao, Y.; Wu, X.; Jiang, T.; Zhang, L.; Fan, X.; et al. Involvement of OsPht1;4 in phosphate acquisition and mobilization facilitates embryo development in rice. Plant J. 2015, 82, 556-569. [CrossRef] [PubMed]

38. Nagarajan, V.K.; Jain, A.; Poling, M.D.; Lewis, A.J.; Raghothama, K.G.; Smith, A.P. Arabidopsis Pht1;5 mobilizes phosphate between source and sink organs and influences the interaction between phosphate homeostasis and ethylene signaling. Plant Physiol. 2011, 156, 1149-1163. [CrossRef] [PubMed]

39. Jia, H.; Zhang, S.; Wang, L.; Yang, Y.; Zhang, H.; Cui, H.; Shao, H.; Xu, G. OsPht1;8, a phosphate transporter, is involved in auxin and phosphate starvation response in rice. J. Exp. Bot. 2017, 68, 5057-5068. [CrossRef] [PubMed]

40. Wang, Z.; Hu, H.; Huang, H.; Duan, K.; Wu, Z.; Wu, P. Regulation of OsSPX1 and OsSPX3 on expression of OsSPX domain genes and Pi-starvation signaling in rice. J. Integr. Plant Biol. 2009, 51, 663-674. [CrossRef] [PubMed]

41. Puga, M.I.; Mateos, I.; Charukesi, R.; Wang, Z.; Franco-Zorrilla, J.M.; de Lorenzo, L.; Irigoyen, M.L.; Masiero, S.; Bustos, R.; Rodríguez, J.; et al. SPX1 is a phosphate-dependent inhibitor of Phosphate Starvation Response 1 in Arabidopsis. Proc. Natl. Acad. Sci. USA 2014, 111, 14947-14952. [CrossRef] [PubMed]

42. Shi, J.; Hu, H.; Zhang, K.; Zhang, W.; Yu, Y.; Wu, Z.; Wu, P. The paralogous SPX3 and SPX5 genes redundantly modulate Pi homeostasis in rice. J. Exp. Bot. 2014, 65, 859-870. [CrossRef] [PubMed]

43. Wang, Z.; Ruan, W.; Shi, J.; Zhang, L.; Xiang, D.; Yang, C.; Li, C.; Wu, Z.; Liu, Y.; Yu, Y.; et al. Rice SPX1 and SPX2 inhibit phosphate starvation responses through interacting with PHR2 in a phosphate-dependent manner. Proc. Natl. Acad. Sci. USA 2014, 111, 14953-14958. [CrossRef] [PubMed]

44. Wild, R.; Gerasimaite, R.; Jung, J.Y.; Truffault, V.; Pavlovic, I.; Schmidt, A.; Saiardi, A.; Jessen, H.J.; Poirier, Y.; Hothorn, M.; Mayer, A. Control of eukaryotic phosphate homeostasis by inositol polyphosphate sensor domains. Science 2016, 352, 986-990. [CrossRef] [PubMed]

45. Liu, N.; Shang, W.; Li, C.; Jia, L.; Wang, X.; Xing, G.; Zheng, W. Evolution of the SPX gene family in plants and its role in the response mechanism to phosphorus stress. Open Biol. 2018, 8, 170231. [CrossRef] [PubMed]

46. Baek, D.; Chun, H.J.; Yun, D.J.; Kim, M.C. Cross-talk between phosphate starvation and other environmental stress signaling pathways in plants. Mol. Cells 2017, 40, 697-705. [CrossRef] [PubMed]

47. Martínez-Andújar, C.; Ruiz-Lozano, J.M.; Dodd, I.C.; Albacete, A.; Pérez-Alfocea, F. Hormonal and nutritional features in contrasting rootstock-mediated tomato growth under low-phosphorus nutrition. Front. Plant Sci. 2017, 11, 533. [CrossRef] [PubMed]

48. Park, B.S.; Seo, J.S.; Chua, N.H. NITROGEN LIMITATION ADAPTATION recruits PHOSPHATE2 to target the phosphate transporter PT2 for degradation during the regulation of Arabidopsis phosphate homeostasis. Plant Cell 2014, 26, 454-464. [CrossRef] [PubMed]

49. Kant, S.; Peng, M.; Rothstein, S.J. Genetic regulation by NLA and microRNA827 for maintaining nitrate-dependent phosphate homeostasis in arabidopsis. PLoS Genet. 2011, 7, e1002021. [CrossRef] [PubMed]

50. Israel, D.W. Investigation of the role of phosphorus in symbiotic dinitrogen fixation. Plant Physiol. 1987, 84, 835-840. [CrossRef] [PubMed]

51. Li, X.; Zhao, J.; Tan, Z.; Zeng, R.; Liao, H. GmEXPB2, a cell wall $\beta$-expansin, affects soybean nodulation through modifying root architecture and promoting nodule formation and development. Plant Physiol. 2015, 169, 2640-2653. [CrossRef] [PubMed] 
52. Herridge, D.F.; Peoples, M.B.; Boddey, R.M. Global inputs of biological nitrogen fixation in agricultural systems. Plant Soil 2008, 311, 1-18. [CrossRef]

53. Peoples, M.B.; Brockwell, J.; Herridge, D.F.; Rochester, I.J.; Alves, B.J.R.; Urquiaga, S.; Boddey, R.M.; Dakora, F.D.; Bhattarai, S.; Maskey, S.L.; et al. The contributions of nitrogen-fixing crop legumes to the productivity of agricultural systems. Symbiosis 2009, 48, 1-17. [CrossRef]

54. Ferguson, B.J.; Mathesius, U. Phytohormone regulation of legume-rhizobia interactions. J. Chem. Ecol. 2014, 40, 770-790. [CrossRef] [PubMed]

55. Liu, H.; Zhang, C.; Yang, J.; Yu, N.; Wang, E. Hormone modulation of legume-rhizobial symbiosis. J. Integr. Plant Biol. 2018, 60, 632-648. [CrossRef] [PubMed]

56. Miyata, K.; Kawaguchi, M.; Nakagawa, T. Two distinct EIN2 genes cooperatively regulate ethylene signaling in Lotus japonicus. Plant Cell Physiol. 2013, 54, 1469-1477. [CrossRef] [PubMed]

57. Maekawa, T.; Maekawa-Yoshikawa, M.; Takeda, N.; Imaizumi-Anraku, H.; Murooka, Y.; Hayashi, M. Gibberellin controls the nodulation signaling pathway in Lotus japonicus. Plant J. 2009, 58, 183-194. [CrossRef] [PubMed]

58. Fonouni-Farde, C.; Tan, S.; Baudin, M.; Brault, M.; Wen, J.; Mysore, K.S.; Niebel, A.; Frugier, F.; Diet, A. DELLA-mediated gibberellin signalling regulates Nod factor signalling and rhizobial infection. Nat. Commun. 2016, 2, 12636. [CrossRef] [PubMed]

59. Jin, Y.; Liu, H.; Luo, D.; Yu, N.; Dong, W.; Wang, C.; Zhang, X.; Dai, H.; Yang, J.; Wang, E. DELLA proteins are common components of symbiotic rhizobial and mycorrhizal signalling pathways. Nat. Commun. 2016, 12, 12433. [CrossRef] [PubMed]

60. Schulze, J.; Temple, G.; Temple, S.J.; Beschow, H.; Vance, C.P. Nitrogen fxation by white lupin under phosphorus deficiency. Ann. Bot. 2006, 98, 731-740. [CrossRef] [PubMed]

61. Chen, Z.; Cui, Q.; Liang, C.; Sun, L.; Tian, J.; Liao, H. Identification of differentially expressed proteins in soybean nodules under phosphorus deficiency through proteomic analysis. Proteomics 2011, 11, 4648-4659. [CrossRef] [PubMed]

62. Qin, L.; Zhao, J.; Tian, J.; Chen, L.; Sun, Z.; Guo, Y.; Lu, X.; Gu, M.; Xu, G.; Liao, H. The high-affinity phosphate transporter GmPT5 regulates phosphate transport to nodules and nodulation in soybean. Plant Physiol. 2012, 159, 1634-1643. [CrossRef] [PubMed]

63. Ding, X.; Sui, X.; Wang, F.; Gao, J.; He, X.; Zhang, F.; Yang, J.; Feng, G. Synergistic interactions between Glomus mosseae and Bradyrhizobium japonicum in enhancing proton release from nodules and hyphae. Mycorrhiza 2012, 22, 51-58. [CrossRef] [PubMed]

64. Hernández, G.; Valdés-López, O.; Ramírez, M.; Goffard, N.; Weiller, G.; Aparicio-Fabre, R.; Fuentes, S.I.; Erban, A.; Kopka, J.; Udvardi, M.K.; et al. Global changes in the transcript and metabolic profiles during symbiotic nitrogen fixation in phosphorus-stressed common bean plants. Plant Physiol. 2009, 151, 1221-1238. [CrossRef] [PubMed]

65. Cabeza, R.A.; Liese, R.; Lingne, A.; von Stieglitz, I.; Neumann, J.; Salinas-Riester, G.; Pommerenke, C.; Dittert, K.; Schulze, J. RNA-seq transcriptome profiling reveals that Medicago truncatula nodules acclimate $\mathrm{N}_{2}$ fixation before emerging P deficiency reaches the nodules. J. Exp. Bot. 2014, 65, 6035-6048. [CrossRef] [PubMed]

66. Nasr, E.M.; Inoue, K.; Chu, H.D.; Nguyen, K.H.; Van, H.C.; Watanabe, Y.; Burritt, D.J.; Herrera-Estrella, L.; Mochida, K.; Tran, L.P. Comparative transcriptome analysis of nodules of two mesorhizobium-chickpea associations with differential symbiotic efficiency under phosphate deficiency. Plant J. 2017, 91, 911-926. [CrossRef] [PubMed]

67. Valentine, A.J.; Benedito, V.A.; Kang, Y. Legume nitrogen fixation and soil abiotic stress: From physiology to genomics and beyond. In Annual Plant Reviews: Nitrogen Metabolism in Plants in the Post-Genomic Era; Foyer, C.H., Zhang, H., Eds.; WileyBlackwell: Oxford, UK, 2010; Volume 42, pp. 207-248.

68. Amarasinghe, B.H.; de Bruxelles, G.L.; Braddon, M.; Onyeocha, I.; Forde, B.G.; Udvardi, M.K. Regulation of GmNRT2 expression and nitrate transport activity in roots of soybean (Glycine max). Planta 1998, 206, 44-52. [CrossRef] [PubMed]

69. Misson, J.; Raghothama, K.G.; Jain, A.; Jouhet, J.; Block, M.A.; Bligny, R.; Ortet, P.; Creff, A.; Somerville, S.; Rolland, N. A genome-wide transcriptional analysis using Arabidopsis thaliana Affymetrix gene chips determined plant responses to phosphate deprivation. Proc. Natl. Acad. Sci. USA 2005, 102, 11934-11939. [CrossRef] [PubMed] 
70. O'Rourke, J.A.; Yang, S.S.; Miller, S.S.; Bucciarelli, B.; Liu, J.; Rydeen, A.; Bozsoki, Z.; Uhde-Stone, C.; Tu, Z.J.; Allan, D.; et al. An RNA-Seq transcriptome analysis of orthophosphate-deficient white lupin reveals novel insights into phosphorus acclimation in plants. Plant Physiol. 2013, 161, 705-724. [CrossRef] [PubMed]

71. Secco, D.; Jabnoune, M.; Walker, H.; Shou, H.; Wu, P.; Poirier, Y.; Whelan, J. Spatio-temporal transcript profiling of rice roots and shoots in response to phosphate starvation and recovery. Plant Cell 2013, 25, 4285-4304. [CrossRef] [PubMed]

72. Wang, Q.; Wang, J.; Yang, Y.; Du, W.; Zhang, D.; Yu, D.; Cheng, H. A genome-wide expression profile analysis reveals active genes and pathways coping with phosphate starvation in soybean. BMC Genom. 2016, 17, 192. [CrossRef] [PubMed]

73. Ham, B.K.; Chen, J.; Yan, Y.; Lucas, W.J. Insights into plant phosphate sensing and signaling. Curr. Opin. Biotechnol. 2018, 49, 1-9. [CrossRef] [PubMed]

74. Yao, Z.; Tian, J.; Liao, H. Comparative characterization of GmSPX members reveals that GmSPX3 is involved in phosphate homeostasis in soybean. Ann. Bot. 2014, 114, 477-488. [CrossRef] [PubMed]

75. Delhaize, E.; Taylor, P.; Hocking, P.J.; Simpson, R.J.; Ryan, P.R.; Richardson, A.E. Transgenic barley (Hordeum vulgare L.) expressing the wheat aluminum resistance gene (TaALMT1) shows enhanced phosphorus nutrition and grain production when grown on an acid soil. Plant Biotechnol. J. 2009, 7, 391-400. [CrossRef] [PubMed]

76. Lü, J.; Gao, X.; Dong, Z.; Yi, J.; An, L. Improved phosphorus acquisition by tobacco through transgenic expression of mitochondrial malate dehydrogenase from Penicillium oxalicum. Plant Cell Rep. 2012, 31, 49-56. [CrossRef] [PubMed]

77. Liang, C.; Sun, L.; Yao, Z.; Liao, H.; Tian, J. Comparative analysis of PvPAP gene family and their functions in response to phosphorus deficiency in common bean. PLoS ONE 2012, 7, e38106. [CrossRef] [PubMed]

78. Liu, X.; Zhao, X.; Zhang, L.; Lu, W.; Li, X.; Kai, X. TaPht1;4, a high-affinity phosphate transporter gene in wheat (Triticum aestivum), plays an important role in plant phosphate acquisition under phosphorus deprivation. Funct. Plant Biol. 2013, 40, 329-341. [CrossRef]

79. Wang, L.; Lu, S.; Zhang, Y.; Li, Z.; Du, X.; Liu, D. Comparative genetic analysis of Arabidopsis purple acid phosphatases AtPAP10, AtPAP12, and AtPAP26 provides new insights into their roles in plant adaptation to phosphate deprivation. J. Integr. Plant Biol. 2014, 56, 299-314. [CrossRef] [PubMed]

80. Remy, E.; Cabrito, T.R.; Batista, R.A.; Teixeira, M.C.; Sá-Correia, I.; Duque, P. The Pht1;9 and Pht1;8 transporters mediate inorganic phosphate acquisition by the Arabidopsis thaliana root during phosphorus starvation. New Phytol. 2012, 195, 356-371. [CrossRef] [PubMed]

81. Liu, P.D.; Xue, Y.B.; Chen, Z.J.; Liu, G.D.; Tian, J. Characterization of purple acid phosphatases involved in extracellular dNTP utilization in Stylosanthes. J. Exp. Bot. 2016, 67, 4141-4154. [CrossRef] [PubMed]

82. Tran, H.T.; Hurley, B.A.; Plaxton, W.C. Feeding hungry plants: The role of purple acid phosphatases in phosphate nutrition. Plant Sci. 2010, 179, 14-27. [CrossRef]

83. Tian, J.; Liao, H. The role of intracellular and secreted purple acid phosphatases in plant phosphorus scavenging and recycling. Annu. Plant Rev. 2015, 48, 265-287.

84. Hegeman, C.E.; Grabau, E.A. A novel phytase with sequence similarity to purple acid phosphatases is expressed in cotyledons of germinating soybean seedlings. Plant Physiol. 2001, 126, 1598-1608. [CrossRef] [PubMed]

85. Liao, H.; Wong, F.L.; Phang, T.H.; Cheung, M.Y.; Li, W.Y.; Shao, G.; Yan, X.; Lam, H.M. GmPAP3, a novel purple acid phosphatase-like gene in soybean induced by $\mathrm{NaCl}$ stress but not phosphorus deficiency. Gene 2003, 318, 103-111. [CrossRef]

86. Kong, Y.; Li, X.; Ma, J.; Li, W.; Yan, G.; Zhang, C. GmPAP4, a novel purple acid phosphatase gene isolated from soybean (Glycine max), enhanced extracellular phytate utilization in Arabidopsis thaliana. Plant Cell Rep. 2014, 33, 655-667. [CrossRef] [PubMed]

87. Li, C.; Li, C.; Zhang, H.; Liao, H.; Wang, X. The purple acid phosphatase GmPAP21 enhances internal phosphorus utilization and possibly plays a role in symbiosis with rhizobia in soybean. Physiol. Plant 2017, 159, 215-227. [CrossRef] [PubMed]

88. Zhang, J.; Zhou, X.; Xu, Y.; Yao, M.; Xie, F.; Gai, J.; Li, Y.; Yang, S. Soybean SPX1 is an important component of the response to phosphate deficiency for phosphorus homeostasis. Plant Sci. 2016, 248, 82-91. [CrossRef] [PubMed] 
89. Nasr, E.M.; Kusano, M.; Nguyen, K.H.; Watanabe, Y.; Ha, C.V.; Saito, K.; Sulieman, S.; Herrera-Estrella, L.; Tran, L.S. Adaptation of the symbiotic Mesorhizobium-chickpea relationship to phosphate deficiency relies on reprogramming of whole-plant metabolism. Proc. Natl. Acad. Sci. USA 2016, 113, E4610-E4619. [CrossRef] [PubMed]

90. Gaufchon, L.; Reisdorf-Cren, M.; Rothstein, S.J.; Chardon, F.; Suzuki, A. Biological functions of asparagine synthetase in plants. Plant Sci. 2010, 179, 141-153. [CrossRef]

91. Sulieman, S.; Fischinger, S.A.; Gresshoff, P.M.; Schulze, J. Asparagine as a major factor in the N-feedback regulation of $\mathrm{N}_{2}$ fixation in Medicago truncatula. Physiol. Plant 2010, 140, 21-31. [CrossRef] [PubMed]

92. Sulieman, S.; Tran, L.S.P. Asparagine: An amide of particular distinction in the regulation of symbiotic nitrogen fixation of legumes. Crit. Rev. Biotechnol. 2013, 33, 309-327. [CrossRef] [PubMed]

93. Turner, M.; Nizampatnam, N.R.; Baron, M.; Coppin, S.; Damodaran, S.; Adhikari, S.; Arunachalam, S.P.; Yu, O.; Subramanian, S. Ectopic expression of miR160 results in auxin hypersensitivity, cytokinin hyposensitivity, and inhibition of symbiotic nodule development in soybean. Plant Physiol. 2013, 162, 2042-2055. [CrossRef] [PubMed]

94. Miwa, H.; Sun, J.; Oldroyd, G.E.D.; Downie, J.A. Analysis of calcium spiking using a cameleon calcium sensor reveals that nodulation gene expression is regulated by calcium spike number and the developmental status of the cell. Plant J. 2006, 48, 883-894. [CrossRef] [PubMed]

95. Dodd, A.N.; Kudla, J.; Sanders, D. The language of calcium signaling. Annu. Rev. Plant Biol. 2010, 61, 593-620. [CrossRef] [PubMed]

96. Singh, S.; Parniske, M. Activation of calcium- and calmodulin-Dependent protein kinase (CCaMK), the central regulator of plant root endosymbiosis. Curr. Opin. Plant Biol. 2012, 15, 444-453. [CrossRef] [PubMed]

97. Kang, H.; Chu, X.; Wang, C.; Xiao, A.; Zhu, H.; Yuan, S.; Yang, Z.; Ke, D.; Xiao, S.; Hong, Z.; et al. A MYB coiled-coil transcription factor interacts with NSP2 and is involved in nodulation in Lotus japonicus. New Phytol. 2014, 201, 837-849. [CrossRef] [PubMed]

98. Hirsch, S.; Kim, J.; Munoz, A.; Heckmann, A.B.; Downie, J.A.; Oldroyd, G.E. GRAS proteins form a DNA binding complex to induce gene expression during nodulation signaling in Medicago truncatula. Plant Cell 2009, 21, 545-557. [CrossRef] [PubMed]

99. Murphy, J.; Riley, J. A modifed single solution method for the determination of phosphate in natural water. Anal. Chim. Acta 1962, 27, 31-36. [CrossRef]

100. Bradford, M.M. A rapid and sensitive method for the quantitation of microgram quantities of protein utilizing the principle of protein-dye binding. Anal. Biochem. 1976, 72, 248-254. [CrossRef]

101. Vadez, V.; Beck, D.P.; Lasso, J.H.; Drevon, J.J. Utilization of the acetylene reduction assay to screen for tolerance of symbiotic $\mathrm{N}_{2}$, fixation to limiting P nutrition in common bean. Physiol. Plant 1997, 99, 227-232. [CrossRef]

102. Wang, M.; Ma, H.; Tian, C.; Liu, S.; Ye, X.; Zhou, D.; Li, Y.; Hui, N.; Li, X. Bioassay-guided isolation of glycoprotein SPG-56 from sweet potato Zhongshu-1 and its anti-colon cancer activity in vitro and in vivo. J. Funct. Foods 2017, 35, 315-324. [CrossRef]

103. Trapnell, C.; Roberts, A.; Goff, L.; Pertea, G.; Kim, D.; Kelley, D.R.; Pimentel, H.; Salzberg, S.L.; Rinn, J.L.; Pachter, L. Differential gene and transcript expression analysis of RNA-seq experiments with TopHat and Cufflinks. Nat. Protoc. 2012, 7, 562-578. [CrossRef] [PubMed]

104. Trapnell, C.; Williams, B.A.; Pertea, G.; Mortazavi, A.; Kwan, G.; van Baren, M.J.; Salzberg, S.L.; Wold, B.J.; Pachter, L. Transcript assembly and quantification by RNA-Seq reveals unannotated transcripts and isoform switching during cell differentiation. Nat. Biotechnol. 2010, 28, 511-515. [CrossRef] [PubMed]

105. Wang, L.; Feng, Z.; Wang, X.; Zhang, X. DEGseq: An R package for identifying differentially expressed genes from RNA-seq data. Bioinformatics 2010, 26, 136-138. [CrossRef] [PubMed]

106. Huang, D.W.; Sherman, B.T.; Lempicki, R.A. Systematic and integrative analysis of large gene lists using DAVID bioinformatics resources. Nat. Protoc. 2009, 4, 44-57. [CrossRef] [PubMed]

107. Thimm, O.; Bläsing, O.; Gibon, Y.; Nagel, A.; Meyer, S.; Krüger, P.; Selbig, J.; Müller, L.A.; Rhee, S.Y.; Stitt, M. MapMan: A user-driven tool to display genomic data sets onto diagrams of metabolic pathways and other biological processes. Plant J. 2004, 37, 914-939. [CrossRef] [PubMed]

108. Tamura, K.; Dudley, J.; Nei, M.; Kumar, S. MEGA4: Molecular Evolutionary Genetics Analysis (MEGA) software version 4.0. Mol. Biol. Evol. 2007, 24, 1596-1599. [CrossRef] [PubMed] 
109. Paszkowski, U.; Kroken, S.; Roux, C.; Briggs, S.P. Rice phosphate transporters include an evolutionarily divergent gene specifically activated in arbuscular mycorrhizal symbiosis. Proc. Natl. Acad. Sci. USA 2002, 99, 13324-13329. [CrossRef] [PubMed]

110. Liu, J.; Versaw, W.K.; Pumplin, N.; Gomez, S.K.; Blaylock, L.A.; Harrison, M.J. Closely related members of the Medicago truncatula PHT1 phosphate transporter gene family encode phosphate transporters with distinct biochemical activities. J. Biol. Chem. 2008, 283, 24673-24681. [CrossRef] [PubMed]

111. Li, D.; Zhu, H.; Liu, K.; Liu, X.; Leggewie, G.; Udvardi, M.; Wang, D. Purple acid phosphatases of Arabidopsis thaliana. Comparative analysis and differential regulation by phosphate deprivation. J. Biol. Chem. 2002, 277, 27772-27781. [CrossRef] [PubMed]

112. Zhang, Q.; Wang, C.; Tian, J.; Li, K.; Shou, H. Identification of rice purple acid phosphatases related to phosphate starvation signalling. Plant Biol. 2011, 13, 7-15. [CrossRef] [PubMed]

113. Xiao, K.; Katagi, H.; Harrison, M.; Wang, Z.Y. Improved phosphorus acquisition and biomass production in Arabidopsis, by transgenic expression of a purple acid phosphatase gene from m. truncatula. Plant Sci. 2006, 170, 191-202. [CrossRef]

(C) 2018 by the authors. Licensee MDPI, Basel, Switzerland. This article is an open access article distributed under the terms and conditions of the Creative Commons Attribution (CC BY) license (http:/ / creativecommons.org/licenses/by/4.0/). 